University of Washington Tacoma

UW Tacoma Digital Commons

SIAS Faculty Publications

School of Interdisciplinary Arts and Sciences

$12-1-2011$

\title{
The sedimentology and geomorphology of rock avalanche deposits on glaciers
}

Dan H. Shugar

University of Washington Tacoma, dshugar@uw.edu

John J. Clague

Follow this and additional works at: https://digitalcommons.tacoma.uw.edu/ias_pub

\section{Recommended Citation}

Shugar, Dan H. and Clague, John J., "The sedimentology and geomorphology of rock avalanche deposits on glaciers" (2011). SIAS Faculty Publications. 336.

https://digitalcommons.tacoma.uw.edu/ias_pub/336

This Article is brought to you for free and open access by the School of Interdisciplinary Arts and Sciences at UW Tacoma Digital Commons. It has been accepted for inclusion in SIAS Faculty Publications by an authorized administrator of UW Tacoma Digital Commons. 


\title{
The sedimentology and geomorphology of rock avalanche deposits on glaciers
}

\author{
Shugar, Dan H. ${ }^{1}$ and Clague, John J. \\ Center for Natural Hazard Research, Department of Earth Sciences, Simon Fraser University, \\ Burnaby, British Columbia, BC, Canada, V5A 1S6 \\ ${ }^{1}$ corresponding author: dshugar@sfu.ca 778.782.7203 (ph), 778.782.4198 (fax)
}

\begin{abstract}
We describe and compare the deposits of four large landslides on two glaciers in Alaska using field mapping and remote sensing. We use digital image analysis to compare the sedimentological characteristics of nearly 200,000 individual surface blocks deposited by three landslides at Black Rapids Glacier in 2002. The debris sheets of one of the three landslides on Black Rapids Glacier and a landslide emplaced on Sherman Glacier in 1964 are also investigated. The three landslides on Black Rapids Glacier have undergone little post-depositional modification by glacier flow, whereas the Sherman Glacier landslide has been transported supraglacially up to $\sim 1 \mathrm{~km}$ over the past 46 years. The three debris sheets on Black Rapids Glacier have coarse blocky rims at their distal edges, and all four debris sheets have longitudinal flowbands characterized by differences in texture and produced by shearing within the moving debris. Elongated blocks are parallel to flow, except at the perimeter of the debris sheets, where they are aligned more perpendicular to flow. Blocks on the Sherman Glacier debris sheet have been reoriented by glacier flow. The matrix of all four debris sheets shows no systematic differences with depth or distance from the source. However, it appears to become coarser over a timescale of decades due to weathering.
\end{abstract}

Keywords: Black Rapids Glacier, Sherman Glacier, rock avalanche, landslide, sedimentology, remote sensing 


\section{Introduction}

Rock avalanches are sudden, deep-seated rock-slope failures characterized by rapid and extreme fragmentation of the failed rock mass, high velocities, and long run-outs (Hewitt et al., 2008). Where unimpeded by topography, the flowing debris spreads out over a large area and is deposited as a relatively thin sheet. Most research on rock avalanches has focused on their surface morphology, dynamics, and emplacement mechanisms (Nicoletti \& Sorriso-Valvo, 1991; Hungr, 1995; Davies et al., 1999; Evans et al., 2001, 2009; Davies \& McSaveney, 2002; McDougall \& Hungr, 2005; Locat et al., 2006; McSaveney \& Davies, 2009). However, with some notable exceptions (Cruden \& Hungr, 1986; Hewitt, 1988, 1999; Couture, 1998; Dunning \& Armitage, 2005; Dunning et al., 2005; Crosta et al., 2007), little attention has been paid to the internal structure and sedimentology of rock avalanche deposits. Hewitt (2009) provides one of the few examples of the role of glacier ice in the evolution of a rock avalanche debris sheet, and Shulmeister et al. (2009) discuss the sedimentary and geomorphic characteristics of moraines derived from landslide debris deposited on glaciers. Yet, although research on these aspects of rock avalanches is limited, landslides on glaciers are more common that previously thought (Geertsema et al., 2006; Hewitt, 2009), increasing the need to identify and characterize their deposits.

The sedimentology of rock avalanche deposits assumes importance because diamictons previously thought to be till or terminal moraines have been reinterpreted as landslide debris, with little or no climatic significance (Porter \& Orombelli, 1980; Hewitt, 1999; Larsen et al., 2005; Shulmeister et al., 2009). Hewitt (1999), for example, reinterpreted glacial deposits in the central Karakoram Range in the Himalaya as products of large rock avalanches, thereby casting doubt on the glacial history of the region. Several researchers (Larsen et al., 2005; Tovar et al., 2008; Shulmeister et al., 2009) question the inferred glacial evidence for Late- 
Glacial inter-hemisphere climatic synchroneity by arguing that the Waiho Loop, a conspicuous end moraine deposited by Franz Josef Glacier in New Zealand, comprises rock avalanche debris and does not record atmospheric cooling.

The objectives of this paper are to describe the sedimentology of some rock avalanche deposits on glaciers, to evaluate whether patterns exist within the debris sheets, and to determine whether post-deposition modification due to glacier flow complicates interpretation of the deposits. We describe and compare deposits of three rock avalanches that fell onto Black Rapids Glacier, Alaska, in 2002, and one that fell onto Sherman Glacier, Alaska, in 1964.

The four landslides are large $\left(>10^{6} \mathrm{~m}^{3}\right)$ and had run-outs largely unconstrained by topography.

\section{Study areas}

\subsection{Black Rapids Glacier, Alaska}

Black Rapids Glacier is a 40-km long, surge-type valley glacier in the central Alaska Range of interior Alaska (Figure 1). It has an average width of $\sim 2.3 \mathrm{~km}$ and a mean downvalley slope of $\sim 2^{\circ}$ (Fatland et al., 2003). Its ablation zone lies in an east-trending valley that marks the trace of the Denali Fault. Most of the accumulation zone is in two north-facing valleys, one of which contains the Loket tributary (Figure 1).

The Denali earthquake (M 7.9) in November 2002 triggered three large rock avalanches onto Black Rapids Glacier and others onto nearby Gakona, McGinnis, and West Fork glaciers (Harp et al., 2003; Jibson et al., 2006). Estimates of the total volume of landslide debris emplaced on Black Rapids Glacier range from $25 \times 10^{6}$ to $37 \times 10^{6} \mathrm{~m}^{3}$ (Jibson et al., 2004, 2006), and about $11 \mathrm{~km}^{2}$ of the glacier was covered by the debris (Table 1). The debris consists mainly of quartz diorite and other granitic rocks. Jibson et al. (2004) describe multiple joint sets, both subparallel and orthogonal to the failure planes of the three landslides. Slabs 
30-50 m thick broke along these joints and slid down the $35-38^{\circ}$ slopes. In this paper, we refer to the three landslide debris sheets as BRG-west, BRG-middle and BRG-east.

\subsection{Sherman Glacier, Alaska}

Sherman Glacier is a 12-km long, non-surge-type valley glacier located in the Chugach Mountains of southern Alaska (Figure 1). It has an average width of $\sim 1.5 \mathrm{~km}$ and a mean downvalley slope of $\sim 5^{\circ}$. The glacier flows southwest towards Prince William Sound.

In March 1964, the great Alaska ("Good Friday") earthquake (M 9.2) triggered thousands of landslides across southern Alaska (Keefer, 2002), including many onto glaciers. The largest and best studied of the landslides is the Sherman Glacier rock avalanche, which spread $\sim 14 \mathrm{x}$ $10^{6} \mathrm{~m}^{3}$ debris over $8.3 \mathrm{~km}^{2}$ of the glacier's ablation area (Bull \& Marangunic, 1967; Marangunic \& Bull, 1968; Post, 1968; Tuthill et al., 1968; McSaveney, 1978). The failed rock mass was a pervasively jointed block of greywacke and argillite that slid along a $40^{\circ}$ bedding plane (Shreve, 1966). McSaveney (1975) notes that the landslide scarp is delineated by a set of curved fault planes.

\section{Materials and methods}

We used orthorectified aerial photographs and geomatics tools, in combination with field mapping, to describe morphological and sedimentological features of the rock avalanche debris sheets and to map block ${ }^{1}$ distributions in the deposits. No universally accepted protocols exist for documenting the sedimentology of rock avalanche deposits (Dunning, 2004), although Hewitt (1999) provides a useful checklist for describing related landforms in the field. A major difficulty in describing these deposits is their large range in particle size - from claysize powder (McSaveney \& Davies, 2007) to house-sized blocks.

\footnotetext{
${ }^{1}$ We adopt Neuendorf et al.'s (2005) definition of block - large (>256 mm), angular rock fragments.
} 


\subsection{Grain size distribution}

We used a modified version of Dunning's (2004) method of characterizing the particle size distribution of rock avalanche debris. Dunning developed a sampling strategy, termed the 'Evolved Sample Method' (ESM), for obtaining the distribution of particle size in rock avalanche debris, from $0.002 \mathrm{~mm}$ to $256 \mathrm{~mm}$. The method involves field sieving of the $8-256 \mathrm{~mm}$ fraction and laboratory analysis of the $\leq 8 \mathrm{~mm}$ fraction using a combination of sieving and laser diffraction measurements. In this study, we extended Dunning's technique to particle sizes $>256 \mathrm{~mm}$ using remote sensing.

We used a Malvern Mastersizer 2000 to determine the particle-size distributions ( $<2 \mathrm{~mm}$ ) of 65 matrix samples collected from the debris sheet of the westernmost landslide on Black Rapids Glacier (BRG-west) and 18 samples from the Sherman Glacier debris sheet. Samples were non-cohesive and thus were not pretreated with a dispersant prior to analysis. Dunning (2004) found no differences in analytical results for rock avalanche samples pretreated in a Calgon solution from those dispersed in water alone.

Subsamples (100-200 g) of sediment were wet-sieved on a $0.063-\mathrm{mm}$ screen to remove silt and clay. The remaining sediment was oven-dried $\left(24 \mathrm{~h}\right.$ at $\left.105^{\circ} \mathrm{C}\right)$ and then dry sieved for 20 minutes through a nest of full-phi screens from 0.063 to $4 \mathrm{~mm}$, with additional 12.5 and $19 \mathrm{~mm}$ screens. Sediment on each screen was weighed to $0.1 \mathrm{~g}$. No fine sediment was observed adhering to granules and pebbles following dry sieving. Sediment lost during sieving was $<1$ percent and was therefore ignored (Blott \& Pye, 2001).

Volumetric data provided by the Mastersizer 2000 were integrated with weight data obtained by sieving using the technique outlined in the 'Results Emulation' module of the Mastersizer software. Matrix data were processed using the Gradistat grain size distribution and statistics package in Excel (Blott \& Pye, 2001). The program calculates mean, standard deviation, sorting, skewness, and kurtosis using the method of moments (arithmetic and 
geometric values in $\mu \mathrm{m}$, logarithmic values in $\phi$ ) and Folk \& Ward's (1957) graphical method (both $\mu \mathrm{m}$ and $\phi$ ).

\subsection{Fabric analysis}

Clast fabric analysis has been used in many glacial geology studies (Giardino \& Vitek, 1985; Bennett et al., 1999; Benn \& Ringrose, 2001) and some landslide studies (Lundqvist, 1949) to infer mechanisms of transport and deposition. Data collection and analysis, however, are laborious: data typically must be extrapolated from a small number of sites to large areas. Furthermore, fabric studies of rock avalanche deposits are uncommon because of the difficulty of obtaining representative measurements of large clasts (Marangunic \& Bull, 1968; Gates, 1987; Blair, 1999).

Using a Brunton geological compass, we measured the trend and plunge of 50 elongate clasts $(a: b \geq 1.5: 1, a \geq 10 \mathrm{~cm})$ in landslide debris at each of 13 sites on BRG-west and 11 sites on Sherman Glacier. Trends were recorded to the nearest $5^{\circ}$ due to the difficulty of more precisely measuring the a axes of irregularly shaped, elongate clasts.

Bull \& Marangunic (1968) made fabric measurements at Sherman Glacier two years after the 1964 rock avalanche. They report 16 fabric sets, with 63-107 clasts per set; most sets have more than 100 clasts, with a total of 1596 measurements. Their original tabular data no longer exist (C. Marangunic, pers. comm., 2008), but we extracted measurements from stereonets prepared by Bull \& Marangunic (1968). We assumed that points in the stereonets lay at the center of a $10^{\circ}$ grid cell, except in cases where they touched a grid line, in which case the trend or plunge was assigned that line's values. We used the orientation tensor method of Mark (1973) and Woodcock (1977) to calculate eigenvectors, such that the normalized eigenvectors $S_{1}+S_{2}+S_{3}=1$. 
To document spatial variations in block size and orientation, and thus gain insight into clast transport processes, we created maps of blocks in the landslide debris on Black Rapids Glacier using a digital photo-sieving method, modified from Ibbeken \& Schleyer (1986). Photosieving is a method of grain-size analysis of coarse sediment, performed by manually tracing the outline of each clast on photographs. Ibbeken \& Schleyer (1986) claim that the method is as accurate as traditional sieving methods provided that image resolution is sufficiently high, although they did not offer quantitative data to support their assertion. In this study, we photosieved blocks on three landslides using large-scale orthophotographs and commercial GIS software.

Vertical aerial photographs (scale 1:20,000) of Black Rapids Glacier were taken on September 7, 2004. We created a 10-m digital elevation model (DEM) of the three debris sheets and their environs on an Intergraph softcopy workstation using standard digital photogrammetric techniques (Cox \& March, 2004; Schiefer \& Gilbert, 2007) to remove distortions generated by uneven surface topography, lens imperfections, and yaw, pitch, and roll of the aircraft. We then constructed a color-corrected orthophotograph mosaic with $0.25 \mathrm{~m}$ pixels. The Black Rapids Glacier images were taken less than two years after the landslides and thus likely record the debris sheet prior to significant glacial modification.

We manually digitized individual blocks $\leq 1 \mathrm{~m}^{2}$ in ArcGIS (Figure 2). We then computed the minimum area of a bounding rectangle for each identified block using Patterson's (2008) Bounding Containers toolbox for ArcGIS. The toolbox computes the smallest rectangle possible around a polygon and calculates its length (a-axis), width (b-axis), azimuth, and the coordinates of its center. We analyzed the results using two tools - Hot Spot spatial clustering and neighbourhood statistics. For a set of data points, the local Getis Ord Gi* (Hot Spot) statistic identifies areas with fewer or more points than would be expected by random chance based on the distribution of the entire population. $\mathrm{Gl}^{*}$ is calculated by summing the number of 
neighbors and dividing that value by the number of all features in the study area (Mitchell, 1999). The result is a map of $\mathrm{Gi}^{*} \mathrm{Z}$-scores (standard deviation) for each input point. A high $\mathrm{Gi}^{*}$ value indicates a cluster or concentration of features with high attribute values, in this case, block length. Conversely, a group of features with low $\mathrm{Gi}^{*}$ values indicates a cold spot. This statistic, however, retains no information about the relative sizes of clasts.

To gain additional insight into the spatial distribution of blocks, we calculated the median and maximum (a-axis) block size within squares measuring $25 \mathrm{~m} \times 25 \mathrm{~m}$ using the spatial statistics toolbox in ArcGIS. This tool calculates an output value for each non-overlapping neighborhood based on the values identified in each $625 \mathrm{~m}^{2}$ square within the neighborhood. The result is a series of raster maps of median (d50) and maximum grain size for the entire debris sheet.

We digitized more than 194,000 blocks on the three debris sheets on Black Rapids Glacier (Table 2). Long axis clusters were identified using the Hot Spot tool; median (d50) and maximum block length within neighborhoods were mapped using the spatial statistics described above. Block statistics within a circular neighbourhood with a radius of $50 \mathrm{~m}$ were then extracted along the approximate flow path of each debris sheet. In this way, median block length along the flow path could be calculated and compared with travel distance.

To analyze and interpret the block orientations, we digitized flowbands (e.g. Figure 3) within the debris sheets visible on the orthophotos and interpolated the azimuth values over the landslide deposit. Each 10 m-long flowband line segment was converted to a unit vector, split into its scalar components, and interpolated separately. The interpolations were then combined by calculating the inverse tangent of each pixel. The resulting map contains a flow direction for each pixel on the debris surface. We then calculated the angular deviation of the a-axis of each rod-shaped $(a: b \geq 1.5)$ block from the landslide flow direction and produced a map of deviations for each rod-shaped block on the debris sheet. Our analysis assumes that the $a: b$ 
planes of blocks are horizontal, or nearly so. Observations in the field indicate that this assumption is valid (see section 4.3).

Our analysis of fabric data depends critically on the accuracy of the flow lines drawn in the GIS. Fortunately, the conspicuous flowbands on the debris sheets of Black Rapids Glacier are reliable flow indicators. The three landslides on Black Rapids Glacier moved down-glacier slightly as they crossed the medial moraine; this change in direction is faithfully recorded by the flowbands (Figure 3). What appear to be crossing flow features are visible in the interior of the BRG-middle debris sheet. These features may indicate secondary flow (Kelfoun et al., 2008), but, could also reflect tensile fractures in the underlying ice due to glacier flow. Although the flowbands are conspicuous in the orthoimagery, caution is required when interpreting the results.

\section{Results}

We first describe the general morphology of the landslide debris sheets at our two study sites. We then present the particle-size distributions of the matrix of the westernmost debris sheet on Black Rapids Glacier (BRG-west) and the debris sheet on Sherman Glacier. Finally, we report field fabric measurements and fabric data derived from remote sensing observations at Black Rapids Glacier.

\subsection{General surface morphology}

\subsubsection{Black Rapids Glacier landslides}

The three Black Rapids Glacier landslides differ in their morphologies and volumes, although all display similar runout features. All three landslides detached from steep northfacing rock slopes on the south side of the valley occupied by Black Rapids Glacier. The landslides flowed across the glacier, overtopping a medial moraine up to $\sim 25 \mathrm{~m}$ high, and 
spread out over a total area of $11 \mathrm{~km}^{2}$ (Table 1). They came to rest after reaching the north side of the glacier. The debris sheets are uniformly thin; our fieldwork indicates the average thickness of the debris of the westernmost landslide is 2-3 m, yielding an estimated deposit volume of $22-33 \times 10^{6} \mathrm{~m}^{3}$.

The smallest and westernmost of the three landslides (BRG-west) flowed over the medial moraine near the center of the glacier and came to rest on the debris-covered northern margin of the glacier, $3.4 \mathrm{~km}$ from the source. It has a Fahrböschung, $\mathrm{F}(\mathrm{H} / \mathrm{L}$ expressed as an angle) of $12.1^{\circ}$ (Table 1). The medial moraine altered the path of the debris at the east and west margins of the landslide. The debris sheet contains numerous longitudinal flowbands (sensu Dufresne \& Davies, 2009) and transverse ridges, concentrated on the proximal side of the medial moraine. The longitudinal flowbands are 30-100 m wide and are defined by alternating stripes of fine debris and coarse blocks. Finer stripes are less common and narrower than bands of coarse blocks. No significant differences in relief were observed between the fine and coarse stripes, and no longitudinal grooves are present, as at Sherman Glacier (McSaveney, 1975). Boundaries between debris stripes are typically sharp. There is also a distal rim of very large blocks at the north edge of the debris sheet, which are clast-supported and form a thicker deposit than elsewhere on the debris sheet. Large "jigsaw" brecciated blocks and blocks and cones of disintegrated rock are present over large areas of the BRG-west debris sheet (Figure 3). The latter have cores of competent unweathered rock that are abruptly bordered by loose sandy grus. Two hundred and fifty jigsaw blocks were identified; most are present in the central part of the debris sheet. Seventy-five grussified blocks were observed within a small region in the center of the debris sheet on the proximal side of the medial moraine.

The other two Black Rapids landslides (BRG-middle and BRG-east) also have coarse blocky distal rims and longitudinal flowbands with strong textural and colour differences. Their Fahrböschungs are, respectively, $8.1^{\circ}$ and $13.4^{\circ}$ (Table 1). BRG-middle and BRG-east are 
larger and exhibit more complex flow behaviour than BRG-west. Flowbands on BRG-middle show that the rock avalanche flowed north across Black Rapids Glacier, then turned abruptly to the east on reaching the north lateral moraine and flowed down the glacier (Figure 3); the total travel distance is $5.6 \mathrm{~km}$. The medial moraine at BRG-middle is near the south margin of the glacier and forms a more imposing topographic barrier than at BRG-west. Flowbands on BRG-east indicate that some of the debris of that landslide traveled north, then, as at BRGmiddle, swung to the east. However, much of the debris took a more direct path, traveling directly $4.1 \mathrm{~km}$ to the northeast. BRG-east overtopped a looped medial moraine near the center of the glacier. Some BRG-middle debris overtopped the eastern margin of the BRGwest debris sheet, suggesting that the former landslide occurred just before the latter and flowed unconfined across the glacier. The BRG-middle debris sheet was partially confined where it came into contact with BRG-west on the north side of the medial moraine. BRG-east flowed with no confinement, either debris or moraines.

The landslide debris on Black Rapids Glacier is an effective insulator, reducing melt during summer. Between 2002 and 2007, the debris sheets on Black Rapids Glacier have shut off or substantially reduced ablation, resulting in debris-covered pedestals $\sim 15 \mathrm{~m}$ above the surrounding bare ice surface.

\subsubsection{Sherman Glacier landslide}

When it was deposited, the tongue-shaped debris sheet of the Sherman Glacier landslide resembled that of BRG-west. The debris sheet covered $8.3 \mathrm{~km}^{2}$ of the glacier to an average depth of $1.7 \mathrm{~m}$ (McSaveney, 1978). The rock avalanche traveled $6 \mathrm{~km}$ along a front up to 3.7 km wide. It had a Fahrböschung of $10.2^{\circ}$ (Table 1). Sub-parallel grooves and flowbands delineated the travel direction of the landslide and showed that the debris extended as it flowed down-glacier. The original debris margin was digitate. Fissures transverse to the 
direction of flow were common in the distal part of the debris sheet, and transverse ridges were concentrated at its northeast corner. Shreve (1968) describes a raised distal rim at the edge of the debris sheet, but this observation is questioned by McSaveney (1975). Shreve (1966) noted the presence of jigsaw blocks on the debris sheet, but few were observed during fieldwork in 2008.

In the nearly five decades since the landslide, the debris sheet has been transported southwest by Sherman Glacier; some of the debris is now at the glacier terminus. Some blocks have tumbled down the steep terminal face of the glacier and are accumulating as a moraine. The distal arcuate lobes that characterized the fresh debris sheet have been extensively modified by glacier flow. The debris sheet protects underlying ice from ablation, and the terminus was advancing during our visit in 2008 . The distal part of the debris sheet is vegetated.

\subsection{Matrix particle-size distribution}

\subsubsection{Black Rapids Glacier}

The matrix of the BRG-west debris sheet is muddy sandy gravel and minor sandy gravel; with one exception (sample 003), samples are very poorly sorted to poorly sorted (Figure 4). Sorting, however, improves as mean particle size increases.

Pits were excavated at three sites through the debris sheet to the glacier surface (up to 1.7 m deep), and matrix samples were collected vertically through the debris. No systematic trend in matrix particle size is evident with depth in the debris sheet (Figure 5) or with distance from the source area at BRG-west (Figure 6). The sediment coarsens upward in pit DB3, but there is no systematic trend in matrix particle size in the other two pits (DB2 and "temp pit"; Figure 5).

The particle-size distributions of samples BRG-C, BRG-D, and BRG-I, from the proximal part of the debris sheet, are within the envelope delineated by BRG-F and BRG-K, the most 
distal samples. The matrix of the sample from the medial moraine at site Moraine 1 (Figure 6) is much finer than that of any of the landslide debris samples. A sample at a different location on the same moraine (Moraine 2; Figure 6), however, has a mean particle size similar to that of some of the landslide debris samples, although it is better sorted.

\subsubsection{Sherman Glacier}

The matrix of the Sherman Glacier landslide debris is poorly to moderately sorted, muddy sandy gravel and gravel (Figure 4). Debris pits were excavated at two sites on the debris sheet (Figure 5). Sediment in pit 1 is inversely graded, whereas no systematic vertical trend in particle size is evident in pit 2. Distal samples (Sherman-A, -B, -G) are typically finer than proximal samples (Sherman-E, -I, -J) (Figure 6).

\subsection{Field fabric characterization}

Fabric data collected at Sherman Glacier in 1966 (Marangunic \& Bull, 1968) and 2008 and at BRG-west in 2007 are summarized in Figure 7. All 40 data sets are non-random at the 97.5\% confidence limit, and all except one are significant at the $99 \%$ confidence limit.

Mean orientation vectors are approximately parallel to landslide flow features at both BRGwest and Sherman Glacier (Figure 7). In general, eigenvector plunges are low $\left(<10^{\circ}\right)$, indicating that elongate blocks are lying with their longest axes nearly horizontal. Eigenvectors at BRG-west are mostly aligned parallel to landslide travel direction, except at sites BRG-F and BRG-J, which are located near the margins of the debris sheet.

Most eigenvectors calculated from the 1966 Sherman Glacier fabric data (Figure 7) are parallel to flowbands evident on 1964 aerial photographs. Eigenvectors at two sites at the margin of the debris sheet (sites 10 and 16 in Figure 7), however, are oblique to flowbands. Since 1964, flowbands have become distorted by glacier flow, which is oblique to the original 
travel direction of the landslide. The eigenvectors calculated from data collected in 2008

(Figure 7) display a chevron-like pattern, pointing down-glacier but approximately parallel to flowbands.

\subsection{Remotely sensed fabric}

The Hot Spot cluster analysis reveals patterns of different block sizes on the debris sheets of the three landslides at Black Rapids Glacier. The block size patterns share some characteristics, but are not identical (Figure 8). All three debris sheets have clusters of large blocks in parts of their distal rims, but large blocks are not restricted to those regions and they are not, in all cases, most abundant there. The distal rim with the most conspicuous cluster of large blocks is that of BRG-east. Two clusters of large blocks in the distal rim of BRG-west are small in area relative to a much larger cluster of large blocks in the proximal half of that debris sheet. This larger cluster is almost entirely on the proximal side of the medial moraine. A small cluster of large blocks is present in the extreme southwest corner of the BRG-west debris sheet.

Two clusters of large blocks are present in the northwest corner of the BRG-middle debris sheet. They could be interpreted as one very large cluster, bisected by a narrow stripe of finer blocks. Most of these blocks are on the distal side of the medial moraine, which is closer to the base of the failed slope than at BRG-west or BRG-east. Several small clusters of large blocks occur on the east and north edges of the debris sheet, that is at its down-glacier margin. Clusters of large blocks are common in the distal rim of BRG-east, as well as the proximal region directly south of the medial moraine.

No differences in block size are evident within and between clusters identified with the $\mathrm{Gi}^{*}$ statistic. For insight into intra- and inter-cluster variation, we examined maximum and median (d50) block size within neighborhoods. The map of neighborhood maximum block size (Figure 
8) provides additional information on the distribution of blocks on Black Rapids Glacier.

Although the largest block (26 m) on BRG-west is near the middle of the debris sheet, individual blocks 8-16 m long are common in the distal rim. Large blocks (typically 4-11 m) are also common in the southwest corner of the debris sheet, but they were deposited by a small rockslide that is separate from BRG-west. The remainder of BRG-west is characterized by blocks with maximum sizes of 4-5 $\mathrm{m}$.

Although neighborhoods with large blocks are distributed across much of BRG-middle, the largest blocks occur in three regions: the up-glacier (west) edge of the debris sheet, including the northwest corner; the center of the debris sheet directly north of the medial moraine (Figure 3); and the down-glacier (southeast) edge of the debris sheet. These regions are separated by stripes of finer debris. The largest block (37 $\mathrm{m}$ ) is located in the northwest corner, where neighborhoods with blocks $>10 \mathrm{~m}$ long are common. Many large blocks $(\geq 10 \mathrm{~m})$ are present in the cluster directly north of the medial moraine, although most blocks are $\leq 8 \mathrm{~m}$ long. Large blocks (up to $\sim 12 \mathrm{~m}$ ) are also common at the southeast edge of the debris sheet. The finer stripes separating areas of large blocks include blocks that are typically $\leq 4 \mathrm{~m}$.

The distal reaches of BRG-east are dominated by neighborhoods with maximum block sizes of 4-6 m, although there are some areas with blocks up to $\sim 10 \mathrm{~m}$. The proximal part of the debris sheet is covered by blocks $<4 \mathrm{~m}$ long. Stripes of these finer blocks extend northeast into the distal reaches of BRG-east The largest block on BRG-east is $23 \mathrm{~m}$ long and is located within a train of very large blocks (>12 $\mathrm{m}$ long) in the distal half of the debris sheet. Most of the largest blocks are located within this train and in the distal rim, as at the two other landslides.

The d50 of $25 \times 25$ m neighborhoods within the most distal clusters at BRG-west are typically $\sim 3 \mathrm{~m}$; isolated neighborhoods have d50 up to $5 \mathrm{~m}$ (Figure 9). On the proximal 
side of the medial moraine on BRG-west, however, neighborhood d50 values are typically 3-6 $\mathrm{m}$, with isolated values up to $\sim 9 \mathrm{~m}$. Neighborhoods over the remainder of BRG-west typically have d50 values $<3 \mathrm{~m}$.

Groups of neighborhoods with large blocks (d50 3-6 m) occur at the northwest corner of BRG-middle. Neighborhoods with the largest median values (5-10 m), however, are located in a cluster directly north of the medial moraine. These two regions of larger blocks are bisected by a finer stripe, with typical d50 values of 2-3 m. Elsewhere at BRG-middle, most d50 values are $\leq 3 \mathrm{~m}$.

Most neighborhoods on BRG-east have median block sizes of $\leq 2 \mathrm{~m}$. A few small clusters of larger blocks ( $\sim 3 \mathrm{~m})$ occur at the distal margin, with isolated neighborhoods of 5-8 $\mathrm{m}$ in this area. Neighborhoods with median block size of $3 \mathrm{~m}$ are dominant in the proximal part of the debris sheet, with isolated neighborhoods of $5 \mathrm{~m}$.

Remotely sensed granulometric analysis of blocks on Black Rapids Glacier (Figure 9) reveals complex relationships between block size and travel distance. Of the three debris sheets, only BRG-west shows a statistically significant (significance level $\alpha=0.05$ ) relationship between d50 and travel distance. The coefficient of determination, however, is low for all debris sheets (BRG-west $R^{2}=0.09$; $B R G$-middle $R^{2}=0.002$; BRG-east $R^{2}=0.04$ ). Median block size along axial profiles of BRG-west and BRG-east is large near the source (up to $5.1 \mathrm{~m}$ on BRG-west and $6.4 \mathrm{~m}$ on BRG-east) and rapidly diminishes away from the source. At BRGwest, block length ranges generally from 2 to $3 \mathrm{~m}$ along the transect but coarsens slightly at the distal end. Median block size along the axial profile of BRG-east is typically about $2 \mathrm{~m}$, although it reaches $7.4 \mathrm{~m}$ approximately 80 percent along the transect. Block size along the BRG-middle axial profile is generally larger than at either BRG-west or BRG-east, generally ranging from 2 to $4.5 \mathrm{~m}$, with a maximum of $7.1 \mathrm{~m}$ about 37 percent along the transect. The range in median block size is greater at BRG-middle than at either of the other two landslides. 
Elongate $(a: b \geq 1.5)$ rod-shaped blocks are generally aligned parallel to the direction of flow of the landslide (Figure 8C). Small clusters of landslide-perpendicular blocks are distributed across the debris sheets, most commonly at the edges. A small cluster of landslideperpendicular blocks occurs at the northwest corner of the distal rim of BRG-west. Several clusters of landslide-perpendicular blocks occur at the eastern periphery of BRG-east, and there is one distinct cluster at the western periphery of this debris sheet.

\section{Discussion}

\subsection{Debris sheet shape, flow features, and landslide mobility}

Longitudinal flowbands are present on the debris sheets of the Black Rapids and Sherman glacier landslides, but they are not a characteristic of all rock avalanches. The debris sheet of the 1903 Frank Slide in southern Alberta, for example, does not have flowbands. Dufresne \& Davies (2009) differentiate between flowbands formed by rock avalanches that spread out onto glaciers and longitudinal ridges on the surfaces of other types of landslides. The latter rise up to tens of metres above the surrounding debris surface and generally are restricted to the proximal and medial parts of the debris sheet. In contrast, flowbands are not ridges, commonly extend the full length of the flow, and may be separated from adjacent flowbands by grooves or furrows. Shreve (1968) notes that longitudinal grooves on the Sherman Glacier debris sheet separate bands of different lithologies. Flowbands at Black Rapids Glacier also are characterized by differences in lithology, clast size, and color (Figures 3 and 8 ). The stripes of finer blocks on the debris sheets of Black Rapids Glacier that were identified by the neighborhood analysis (section 4.4) are flowbands.

Dufresne \& Davies (2009) argue that longitudinal flowbands are a fundamental characteristic of granular flows on glaciers. Water derived from the melt of ice and snow mixes with fragmenting rock, fluidizing it and reducing its frictional resistance to flow. Fluidization 
stretches the debris sheet, producing longitudinal bands of debris instead of hummocks or ridges. The absence of flowbands at Frank Slide and other nonglacial rock avalanches may be due to the debris having been dry when deposited.

Transverse compressional ridges are common on most rock avalanche debris sheets, and are present at Black Rapids and Sherman glaciers. Transverse ridges are most common on the proximal side of the medial moraine at Black Rapids Glacier, whereas they are located at the northeast corner of the Sherman Glacier debris sheet. McSaveney (1975) argues that compressional ridges at Sherman Glacier are folds resulting from buckling of the debris sheet as it came to rest. This theory is supported by physical modeling by Dufresne \& Davies (2009), who show that sudden deceleration of the debris, due for example to an encounter with a topographic obstacle, promotes formation of compressional ridges or raised flow fronts. The 25-m-high medial moraine on Black Rapids Glacier was a barrier to flow and induced compression in the debris sheet. Schulz et al. (2008) describe the Black Rapids Glacier landslide deposits as being thicker on the proximal side $(\sim 3 \mathrm{~m})$ than the distal side $(\sim 1-1.5 \mathrm{~m})$ of the moraines, consistent with local compression of the moving debris.

All of the rock avalanches studied here plot below the curve relating volume $(\mathrm{V})$ and the Fahrböschung (Scheidegger, 1973), suggesting that they are anomalously mobile or that, as Strom (2006) suggests, the Fahrböschung is not the best measure of mobility. The angles described here are also at the low end of the spectrum reported by Evans \& Clague (1999) for rock avalanches on glaciers in the Coast and St. Elias Mountains of British Columbia. Strom (2006) suggests that for unconfined rock avalanches, normalized debris apron area or the dimensionless spreading parameter $\mathrm{W}_{\max } \mathrm{W}_{\text {initial }}$ - the maximum width of the debris apron divided by the scarp width - are better metrics of mobility, because friction acts over the entire basal surface and thus landslides that move over unconfined surfaces and form wide aprons are more mobile than those that move mainly in one direction. BRG-west has the smallest 
spreading index of the four landslides we studied (4.8 vs. 5.4-8.6 for the other rock avalanches, Table 1), but values for glacial rock avalanches are generally larger than those for non-glacial rock avalanches such as the Frank Slide (3.1; Nicoletti and Sorriso-Valvo, 1991). Snow and glacier ice enhance mobility of these rock avalanches, causing them to spread more than they would had they had not occurred on glaciers, and consequently, leave much thinner debris sheets, especially in the absence of confinement.

Several authors stress the role played by low-roughness substrates on the mobility and travel distances of landslides that run-out over glaciers. Evans \& Clague $(1988,1999)$, for example, argue that the mobility of rock avalanches emplaced onto glaciers is enhanced by the low friction at the debris-glacier interface. They suggest that friction may be further reduced by water films generated by frictional heating of ice and snow and the development of high pore-water pressures at the base of the debris.

Physical modeling by Friedmann et al. (2006), however, suggests that the properties of granular flows do not depend on the shape or roughness of the substrate. They conducted laboratory experiments on a variety of substrates, ranging from smooth Plexiglass to corrugated cardboard with furrows about ten particle diameters deep, and found that deposit morphology did not change. They suggest that the range of patterns observed in natural deposits may be unrelated to substrate roughness, or that macroscopic features such as raised rims and longitudinal ridges can change from one morphological form to another with little perturbation in movement of the debris. Their experiments, however, do not explicitly mimic glacier substrates - Plexiglass has a higher coefficient of friction than snow and ice, and, of course, there is no frictional melting of Plexiglass or cardboard. McSaveney (1975) estimates that frictional energy may have melted $70 \mathrm{~kg} \mathrm{~m}^{-2}$ of snow beneath the Sherman Glacier rock avalanche. 


\subsection{Spatial patterns of block size}

Many of the largest blocks of the Black Rapids Glacier landslides, including some up to tens of meters in diameter, are concentrated along the peripheries and at the distal edges of the debris sheets (Figure 8). A large Hot Spot cluster with high d50 values occurs in the proximal half of the BRG-west debris sheet, south of the medial moraine (Figures 8 and 9). Caution is required, however, when interpreting the map of neighborhood d50 values, because some areas with high values have low densities of blocks per unit area. For example, the large area of high d50 values in the proximal part of the BRG-west debris sheet has a density of $3000-5000$ blocks per $\mathrm{km}^{2}$, whereas the distal reaches are characterized by densities up to $\sim 32,000$ blocks per $\mathrm{km}^{2}$. The proximal $25 \times 25 \mathrm{~m}$ neighborhoods may contain only a few blocks that skew the median size. The apparent dichotomy of moderate-to-low d50 and large maximum block size at the distal rim of the BRG-west debris sheet reflects poor sorting in that area - very large blocks are scattered among piles of smaller ones. Sorting in the proximal part of the debris sheet is much better, with many blocks of similar size and few very large or very small blocks.

The coarse distal and lateral rims of the Black Rapids Glacier debris sheets are similar to those deposited on glaciers by rock avalanches elsewhere (Rapp, 1959; Shreve, 1959, 1968; Porter \& Orombelli, 1980; Blair, 1999; Hewitt, 1999, 2009; Delaney \& Evans, 2008). It is notable, however, that raised margins are also associated with Martian landslides, although they occur more typically at the lateral margins than at the terminus (Lucchitta, 1979). Most published descriptions of raised rims do not reveal whether the blocks composing the rims are larger than those in the interior of the debris sheet (Shreve, 1959; Eisbacher, 1979; Stock, 2008) or, alternatively, whether more of them are piled up above the surrounding debris surface. Marangunic \& Bull (1968), however, suggest that distal rims at Sherman Glacier were produced by bulldozing of debris over dirty snow. The coarse blocky rims at Black Rapids 
Glacier probably were formed by bulldozing and piling up of very large blocks. The distal rim at BRG-west comprises clast-supported blocks with little interstitial material. In many places, the rim is more than $3 \mathrm{~m}$ thick. The rims contrast with most of the debris sheet, which is finer and thinner and consists of matrix-supported diamicton capped by a coarser blocky carapace. The dearth of matrix in the rim at BRG-west suggests that the leading edge of the debris stream was less fragmented than the trailing body of debris. In this scenario, the coarse distal rims are a product of less intense fracturing, perhaps due to less intense crushing during transport.

Hewitt (2002) points out that rock units in the lowest part of the detachment zone form the distal deposits of rock avalanches. Initial fragmentation of a coherent rock mass occurs during the early stages of transport as the rock moves down the mountainside towards the foot of the slope (Davies et al., 1999), thus rock units lower in the detachment zone will fragment less than higher ones. The occurrence of huge clasts on the upper surface of rock avalanche deposits at Black Rapids Glacier and elsewhere (Dunning, 2006; Strom, 2006) suggests that fragmentation occurs mainly within, rather than at the surface of, the debris sheet.

Fragmentation involves grinding and crushing, and the stresses needed to fracture rocks are greatest within the body of a rock avalanche; surface clasts are rafted, rather than sheared and disaggregated (Davies et al., 1999). Eisbacher (1979) suggests that debris traveling at the front of a rock avalanche is subject to dilation and thinning, an environment not conducive to fragmentation. McSaveney (1978) argues that the Sherman Glacier debris behaved as a Bingham plastic, with minimal grain crushing at the periphery. It is likely that a similar process operated with the landslides on Black Rapids Glacier.

The lack of significant trends in median block size with distance along the axial profiles of the Black Rapids Glacier debris sheets (Figure 9) suggests that either block size on the surface of rock avalanches does not change with distance as suggested by Marangunic and Bull (1968), or axial profiles are not the best descriptor of block size variability. McSaveney 
(1975) argues that irregular topography along the flow path of the Sherman Glacier rock avalanche contributed more to fragmentation of the debris than distance travelled. Based on the complex spatial patterns shown in Figures 8 and 9, we suggest that a 1D transect is not appropriate for describing block size trends in a rock avalanche debris sheet. Instead, much valuable information can be gained by using a combined field-GIS method, such as that described here.

\subsection{Spatial patterns of block orientation}

Mean orientation vectors of elongate blocks at Sherman Glacier (1966 data, Figure 7) and Black Rapids Glacier (Figures 7 and 8) indicate that clasts were aligned parallel to flow. Although flow-induced realignment is the most likely scenario, it is possible that this fabric represents the initial alignment of blocks. Flow-parallel fabrics can result from shear between adjacent semi-coherent bands of debris. Most of the elongate blocks that are perpendicular to flow are in the distal parts of the debris sheets or on the proximal side of the medial moraine at Black Rapids Glacier, suggesting that clasts realign as the landslide slows and comes to rest or as the debris travels over obstacles. Alternatively, this pattern may result from less intense crushing at the leading edge than in the middle of the debris sheet. Blair (1999) describes a similar reorientation of clasts in the North Long John rock avalanche in California.

McSaveney (1978) ascribes the rarer transverse fabric in the Sherman Glacier debris sheet to the rolling of clasts rather than longitudinal stretching of the debris. On the rock avalanche deposits at Black Rapids Glacier, the transverse fabrics are mostly observed at the margins of the debris sheets. A possible explanation is that these marginal blocks rotated shortly after coming to rest as other blocks collided with them. Heim (1882; quoted in Eisbacher, 1979) suggests that the trailing part of a rock avalanche will not overtake the front of the flow, but it will impact the front and push it forward. Strom (1996) argues for a similar mechanism, but 
concludes that if the trailing part of the debris has sufficient kinetic energy, it can outrun the leading edge. Modeling by Davies et al. (1999), however, suggests the opposite occurs longitudinal dispersive forces reduce the debris thickness, causing the trailing debris to decelerate and the leading debris to accelerate.

\subsection{Post-depositional modification of rock avalanche matrix}

The matrix of the landslide debris on Sherman Glacier is coarser and better sorted than that of BRG-west. Samples plot closer to the gravel end of the spectrum of rock avalanche matrices (compare Figure 4 with figure 4 of Dunning \& Armitage, 2005). These differences could reflect different source lithologies, different environments, or lengthy post-depositional modification of the debris on Sherman Glacier. The different lithologies at the two sites (granitoid rocks at Black Rapids Glacier, sandstone and argillite at Sherman Glacier) may influence the degree of fragmentation of blocks during transport. Differences in fall height and runout distance may also affect the degree of crushing, thereby producing different initial particle-size distributions. Finally, much of the original fine matrix in the Sherman Glacier debris may have removed by weathering since 1964 .

We performed a laboratory test to evaluate the effect of the different lithologies on the particle-size distributions of the rock avalanche debris. We crushed nine samples of BRG-west and Sherman Glacier debris using a jaw crusher, disk mill, and pulverizer (10 seconds per sample), and measured the particle-size distributions of the crushed $(<1 \mathrm{~mm})$ matrix. All crushed samples are silty sand, but the samples from Sherman Glacier are slightly coarser than those from BRG-west (Figure 10), suggesting that lithological differences contribute at least partially to the differences in the particle-size distributions. Eyles \& Rogerson (1978) however, report that particle-size distributions of debris on medial moraines of Berendon Glacier in northern British Columbia are independent of bedrock source. Hewitt (2009) 
describes relatively little change to the general morphology of rock avalanche debris sheets on Bualtar Glacier, Pakistan, after 20 years of supraglacial transport. The debris, however, has been substantially reworked over this time. The matrix has been weathered due to deflation by strong katabatic winds.

The Sherman Glacier landslide has a larger vertical travel distance than BRG-west (1.08 km vs. $0.73 \mathrm{~km})$, as well as a longer horizontal travel distance $(6.0 \mathrm{~km}$ vs. $3.4 \mathrm{~km})$. Because fragmentation occurs continuously during transport (Davies et al., 1999), the matrix of rock avalanche debris should fine with distance of travel (Figure 6). Therefore, it seems unlikely that the greater fall height and longer travel distance of the Sherman Glacier landslide contributed to the observed difference in texture between its debris and that of BRG-west.

We compiled particle-size data for seven rock avalanche deposits (four in the $20^{\text {th }}$ century and three that are prehistoric) to elucidate factors responsible for the observed differences between the Sherman and Black Rapids debris (Figure 10). McSaveney and Davies (2007) describe rock avalanche grains in sub-micron sizes down to the resolution of their electron microscope $(\sim 0.077 \mu \mathrm{m})$. The smallest mean diameter measured in the current study is about $0.5 \mu \mathrm{m}$, although it is possible that grains too small for the laser particle size analyzer were present. All but two of the rock avalanche deposits studied here have gravelly matrices that are coarser than almost all the Sherman and Black Rapids samples. The two most recent events the 1980 Mount St. Helens and 1991 Mount Cook landslides - have the finest matrices (muddy sandy gravel) of the eight for which we have data, raising the possibility that at least some of the silt and clay in rock avalanche debris may be removed by weathering and erosion on a decadal timescale. McSaveney (1975) points out that much of the finer size material that may have been on the surface of the Sherman Glacier rock avalanche was removed by rain and melting snow. 
No systematic vertical textural variations were observed in the subsurface debris on BRGwest or Sherman Glacier, and no spatial variations were observed on BRG-west. The matrix of the Sherman Glacier landslide debris, however, fines with increasing distance from the source. Although inverse grading of rock avalanche deposits is described here and elsewhere, it relates only to the capping coarse carapace of blocks above the otherwise massive main body of the debris sheet. Dunning (2006) draws a similar conclusion - no normal or inverse grading is apparent in the landslide deposits he studied.

\subsection{Post-deposition modification to large blocks}

Marangunic \& Bull (1968) measured block fabric at Sherman Glacier in 1966, two years after the landslide. Over this two-year period, the surface of the debris sheet was not significantly modified by differential ablation or glacier motion (C. Marangunic, pers. comm., 2009). The data in Figure 7 (Marangunic \& Bull, 1968) thus come close to characterizing the unmodified landslide debris and can be compared to the measurements we made in 2007, more than 40 years later.

The 1966 measurements show that elongate clasts in the interior of the debris sheet are preferentially oriented parallel to the flow direction of the landslide. This pattern suggests that blocks rotate during flow due to shear within the moving debris mass. Streams of clasts may have moved past each other at different velocities, dragging the larger clasts into parallelism with the overall flow direction. Fabric data collected in 1966 from the periphery of the Sherman Glacier debris sheet are somewhat weaker and more variable - some sets have dominant trends parallel to flowlines and a few are normal to flow. This pattern may reflect mixing near the free boundary at the front of the debris sheet; clasts there are less constrained by their neighbors and may not readily orient parallel to flow. Further, if the leading edge of the debris sheet stalls, trailing debris is compressed behind it, causing frontal elongate clasts to reorient 
perpendicular to flow. After deposition, blocks at the perimeter of the landslide may topple or slide due to differential melt of the adjacent bare ice.

Four decades of supraglacial transport have modified the fabric of the Sherman Glacier debris sheet. The mean orientation vectors in 2008 (Figure 7) were still approximately parallel to flowlines, but have been substantially deformed by glacier flow. Downglacier transport of the debris sheet has been greatest at the center of the glacier and least at the margins.

Modification of the fabric of a rock avalanche debris sheet by glacier flow is not surprising, because the blocks form a continuous thin interlocking sheet. Blocks along the centerline of the glacier move faster than those nearer the margins. These differential movements tend to reorient elongate blocks such that their long axes point downglacier (Figure 7). In cases where the flow direction of the landslide is parallel to the flow direction of the glacier, such as on the eastern half of BRG-middle, it is unclear whether post-deposition glacier flow will rework the debris enough to destroy or reorient block fabrics.

\section{Conclusions}

We describe the geomorphology and sedimentology of four rock avalanche debris sheets, three emplaced during an earthquake in 2002 and one nearly 50 years old in order to characterize the deposits and determine whether glacier motion and weathering significantly affect the debris. The four debris sheets share many characteristics, including a monolithologic mega-breccia texture, lobate form, and lack of vertical gradation except for a coarse surficial carapace. Elongate clasts in the debris sheets are preferentially aligned parallel to the landslide flow direction, and distal coarse rims are found on parts of the three rock avalanche debris sheets on Black Rapids Glacier. Longitudinal flowbands occur on all four debris sheets. 
Since the Sherman Glacier landslide in 1964, glacier flow has reoriented clasts so that they now are nearly parallel to the direction of glacier flow. The finer fraction of the surface debris has been washed away, leaving a coarser, better sorted surface deposit.

An important contribution of this study is the finding that 1D transects do not always portray a complete or appropriate picture of the geomorphology of a landslide deposit. Recent advancements in GIS now allow extremely detailed mapping of 2D and 3D surfaces with relative ease. Future efforts in landslide mapping should make use of this powerful tool.

\section{Acknowledgements}

This work was funded through an NSERC Discovery Grant to Clague and an NSERC-PGSD3 doctoral scholarship, a Geological Society of America Bruce 'Biff' Reed research grant, Northern Scientific Training Program grants, and an Arctic Institute of North America Grant-inAid to Shugar. Generous in-kind support was provided by Marmot Mountain Canada, PetzlCharlet Moser, and Sportiva. We thank Steve Sparks (Aero-Metric Alaska, Fairbanks, Alaska) for providing aerial photographs of Black Rapids Glacier. Mark Hird-Rutter (British Columbia Institute of Technology, Burnaby, British Columbia) helped greatly in producing the digital elevation model of Black Rapids Glacier. Jon Pasher (Environment Canada, Ottawa, Ontario) and Dan Patterson (Carleton University, Ottawa, Ontario) provided invaluable assistance with digital photo-sieving. Cedomir Marangunic (Geoestudios, Santiago, Chile) provided his fabric data from Sherman Glacier, and Mauri McSaveney (GNS Science, Lower Hutt, New Zealand) provided particle-size data for other landslides. McSaveney also assisted in the field at Sherman Glacier and contributed to the formulation of some of the ideas contained in this paper. Denny Capps (Simon Fraser University, Burnaby, British Columbia) and Bernhard Rabus (MacDonald Dettwiler and Associates, Richmond, British Columbia) helped collect data at Black Rapids Glacier. We also thank Erin Pettit (CRREL, Fort Wainright, Alaska) and the US 
Army (Fort Wainright, Alaska) for logistical support at Black Rapids Glacier. We thank Wilfried

Haeberli and two anonymous reviewers for their comments on an earlier draft of the paper.

\section{References}

Benn, D.I. and Ringrose, T.J. (2001) Random variation of fabric eigenvalues: Implications for the use of a-axis fabric data to differentiate till facies. Earth Surf. Proc. Land., 26, 295-306.

Bennett, M.R., Waller, R.I., Glasser, N.F., Hambrey, M.J. and Huddart, D. (1999) Glacigenic clast fabrics: genetic fingerprint or wishful thinking? J. Quatern. Sci., 14, 125-135.

Blair, T.C. (1999) Form, facies, and depositional history of the North Long John rock avalanche, Owens Valley, California. Can. J. Earth Sci., 36, 855-870.

Blott, S.J. and Pye, K. (2001) GRADISTAT: A grain size distribution and statistics package for the analysis of unconsolidated sediments. Earth Surf. Proc. Land., 26, 1237-1248.

Bull, C. and Marangunic, C. (1967) The earthquake-induced slide on the Sherman Glacier, south-central Alaska, and its glaciological effects. In: Physics of Snow and Ice; International Conference on Low Temperature Science, 1, pp. 395-408, Sapporo, Japan.

Bull, C. and Marangunic, C. (1968) Glaciological effects of debris slide on Sherman Glacier. In: The Great Alaska Earthquake of 1964 - Hydrology, Pt. A, pp. 309-317. National Academy of Sciences, Washington, DC.

Couture, R. (1998) Contributions aux aspects physiques et méchaniques des écroulements rocheux. Ph.D. thesis, Université Laval, Laval, QC, 573 pp.

Cox, L.H. and March, R.S. (2004) Comparison of geodetic and glaciological mass-balance techniques, Gulkana Glacier, Alaska, USA. J. Glaciol., 50, 363-370.

Crosta, G.B., Frattini, P. and Fusi, N. (2007) Fragmentation in the Val Pola rock avalanche, Italian Alps. J. Geophys. Res., Earth Surf., 112, doi:10.1029/2005JF000455.

Cruden, D.M. and Hungr, O. (1986) The debris of the Frank Slide and theories of rockslideavalanche mobility. Can. J. Earth Sci., 23, 425-432.

Davies, T.R. and McSaveney, M.J. (2002) Dynamic simulation of the motion of fragmenting rock avalanches. Can. Geotech. J., 39, 789-798.

Davies, T.R., McSaveney, M.J. and Hodgson, K.A. (1999) A fragmentation-spreading model for long-runout rock avalanches. Can. Geotech. J., 36, 1096-1110.

Delaney, K.B. and Evans, S.G. (2008) Application of digital cartographic techniques in the characterization and analysis of catastrophic landslides; the case of the 1997 Mount Munday rock avalanche, British Columbia. In: 4th Canadian Conference on Geohazards: From Cause 
to Management (Eds J. Locat, D. Perret, D. Turmel, D. Demers and S. Leroueil), pp. 141-146, University Laval, Quebec City, QC.

Dufresne, A. and Davies, T.R. (2009) Longitudinal ridges in mass movement deposits. Geomorphology, 105, 171-181.

Dunning, S.A. (2004) Rock avalanches in high mountains. Ph.D. thesis, University of Luton, Luton, 309 pp.

Dunning, S.A. (2006) The grain-size distribution of rock-avalanche deposits in valley confined settings. Italian J. Eng. Geol. and Env., 1, 117-121.

Dunning, S.A. and Armitage, P.J. (2005) The grain-size distribution of rock-avalanche deposits: Implications for natural dam stability. In: Natural and Artificial Rockslide Dams; NATO Science Series: IV, Earth and Environmental Sciences (Eds K. Abdrakhmatov, S.G. Evans, R. Hermanns, G. Scarascia-Mugnozza and A.L. Strom), 133, Springer, Dordrecht.

Dunning, S.A., Petley, D.N., Rosser, N.J. and Strom, A.L. (2005) The morphology and sedimentology of valley confined rock-avalanche deposits and their effect on potential dam hazard. In: Landslide Risk Management: Proc. of the Intl. Conf. on Landslide Risk Management, Vancouver (Eds O. Hungr, R. Fell, R. Couture and E. Eberhardt), pp. 691-701. Taylor \& Francis Group, London.

Eisbacher, G.H. (1979) Cliff collapse and rock avalanches (sturzstroms) in the Mackenzie Mountains, northwestern Canada. Can. Geotech. J., 16, 309-344.

Evans, S.G. and Clague, J.J. (1988) Catastrophic rock avalanches in glacial environments. In: Proc., 5th Intl. Symposium on Landslides (Ed C. Bonnard), 2, 1153-1158, Lausanne, Switzerland.

Evans, S.G. and Clague, J.J. (1999) Rock avalanches on glaciers in the Coast and St. Elias Mountains, British Columbia. In: Slope Stability and Landslides, Proc., 13th Annual Vancouver Geotechnical Conference, Vancouver, BC.

Evans, S.G., Hungr, O. and Clague, J.J. (2001) Dynamics of the 1984 rock avalanche and associated distal debris flow on Mount Cayley, British Columbia, Canada; implications for landslide hazard assessment on dissected volcanoes. Eng. Geol., 61, 29-51.

Evans, S.G., Tutubalina, O.V., Drobyshev, V.N., Chernomorets, S.S., McDougall, S., Petrakov, D.A. and Hungr, O. (2009) Catastrophic detachment and high-velocity long-runout flow of Kolka Glacier, Caucasus Mountains, Russia in 2002. Geomorphology, 105, 314-321.

Eyles, N. and Rogerson, R.J. (1978) Sedimentology of medial moraines on Berendon Glacier, British Columbia, Canada - Implications for debris transport in a glacierized basin. Geol. Soc. Am. Bull., 89, 1688-1693.

Fatland, D.R., Lingle, C.S. and Truffer, M. (2003) A surface motion survey of Black Rapids Glacier, Alaska, USA. Ann. Glaciol., 36, 29-36. 
Folk, R.L. and Ward, W.C. (1957) Brazos River bar (Texas): A study in the significance of grain size parameters. J. Sed. Petrol., 27, 3-26.

Friedmann, S.J., Taberlet, N. and Losert, W. (2006) Rock-avalanche dynamics: insights from granular physics experiments. Intl. J. Earth Sci., 95, 911-919.

Gates, W.C.B. (1987) The fabric of rockslide avalanche deposits. Bull. Assoc. Eng. Geol., 24, 389-402.

Geertsema, M., Clague, J.J., Schwab, J.W. and Evans, S.G. (2006) An overview of recent large catastrophic landslides in northern British Columbia, Canada. Eng. Geol., 83, 120-143.

Giardino, J.R. and Vitek, J.D. (1985) A statistical interpretation of the fabric of a rock glacier. Arctic Alpine Res., 17, 165-177.

Harp, E.L., Jibson, R.W., Kayen, R.E., Keefer, D.K., Sherrod, B.L., Carver, G.A., Collins, B.D., Moss, R.E.S. and Sitar, N. (2003) Landslides and liquefaction triggered by the M 7.9 Denali Fault earthquake of 3 November 2002. GSA Today, August, 4-10.

Heim, A. (1882) Der Bergsturz von Elm. Z. Deut. Gesellschaft Geowissenschaften, 34, 74-115.

Hewitt, K. (1988) Catastrophic landslide deposits in the Karakoram Himalaya. Science, 242, 64-67.

Hewitt, K. (1999) Quaternary moraines vs catastrophic rock avalanches in the Karakoram Himalaya, northern Pakistan. Quat. Res., 51, 220-237.

Hewitt, K. (2002) Styles of rock-avalanche depositional complexes conditioned by very rugged terrain, Karakoram Himalaya, Pakistan. Rev. Eng. Geol., 15, 345-377.

Hewitt, K. (2009) Rock avalanches that travel onto glaciers and related developments, Karakoram Himalaya, Inner Asia. Geomorphology, 103, 66-79.

Hewitt, K., Clague, J.J. and Orwin, J.F. (2008) Legacies of catastrophic rock slope failures in mountain landscapes. Earth Sci. Rev., 87, 1-38.

Hungr, O. (1995) A model for the runout analysis of rapid flow slides, debris flows, and avalanches. Can. Geotech. J., 32, 610-623.

Ibbeken, H. and Schleyer, R. (1986) Photo-sieving - A method for grain-size analysis of coarse-grained, unconsolidated bedding surfaces. Earth Surf. Proc. Land., 11, 59-77.

Jibson, R.W., Harp, E.L., Schulz, W. and Keefer, D.K. (2004) Landslides triggered by the 2002 Denali fault, Alaska, earthquake and the inferred nature of the strong shaking.

Earthquake Spectra, 20, 669-691.

Jibson, R.W., Harp, E.L., Schulz, W. and Keefer, D.K. (2006) Large rock avalanches triggered by the M 7.9 Denali Fault, Alaska, earthquake of 3 November 2002. Eng. Geol., 83, 144-160. 
Keefer, D.K. (2002) Investigating landslides caused by earthquakes - A historical review. Surv. Geophys., 23, 473-510.

Kelfoun, K., Druitt, T. van Wyk de Vries, B. and Guilbaud, M.N. (2008) Topographic reflection of the Socompa debris avalanche, Chile. Bull. Volcanol., 10, 1169-1187.

Larsen, S.H., Davies, T.R.H. and McSaveney, M.J. (2005) A possible coseismic landslide origin of late Holocene moraines of the Southern Alps, New Zealand. NZ J. Geol. Geophys., 48, 311-314.

Locat, P., Couture, R., Leroueil, S., Locat, J. and Jaboyedoff, M. (2006) Fragmentation energy in rock avalanches. Can. Geotech. J., 43, 830-851.

Lucchitta, B.K. (1979) Landslides in Valles Marineris, Mars. J. Geophys. Res., 84, 8097-8113.

Lundqvist, G. (1949) The orientation of the block material in certain species of flow earth. Points of view on method. Geogr. Ann., 31, 335-347.

Marangunic, C. and Bull, C. (1968) The landslide on the Sherman Glacier. In: The Great Alaska Earthquake of 1964 - Hydrology, Pt. A, pp. 383-394. National Academy of Sciences, Washington, DC.

Mark, D.M. (1973) Analysis of axial orientation data, including till fabrics. Geol. Soc. Am. Bull., 84, 1369-1373.

McDougall, S. and Hungr, O. (2005) Dynamic modelling of entrainment in rapid landslides. Can. Geotech. J., 42, 1437-1448.

McSaveney, M.J. (1975) The Sherman Glacier rock avalanche of 1964: Its emplacement and subsequent effects on the glacier beneath it. Ph.D. thesis, Ohio State University, Columbus, $\mathrm{OH}, 403 \mathrm{pp}$.

McSaveney, M.J. (1978) Sherman Glacier rock avalanche, Alaska, U.S.A. In: Rockslides and Avalanches, 1 Natural Phenomena (Ed B. Voight), pp. 197-258. Elsevier, Amsterdam.

McSaveney, M.J. and Davies, T.R. (2007) Rockslides and their motion. In: Progress in Landslide Science (Eds K. Sassa, H. Fukuoka, F. Wang and G. Wang), pp. 113-133. SpringerVerlag, Berlin.

McSaveney, M.J. and Davies, T.R. (2009) Surface energy is not one of the energy losses in rock comminution. Eng. Geol., 109, 109-113.

Mitchell, A. (1999) The ESRI Guide to GIS Analysis Volume 2: Spatial Measurements \& Statistics ESRI Press, Redlands, CA, 238 pp.

Nicoletti, P.G. and Sorriso-Valvo, M. (1991) Geomorphic controls of the shape and mobility of rock avalanches. Geol. Soc. Am. Bull., 103, 1365-1373. 
Patterson, D.E. (2008) Bounding Containers ArcGIS Toolbox. http://arcscripts.esri.com/details.asp?dbid=14535. Accessed October 1, 2008.

Porter, S.C. and Orombelli, G. (1980) Catastrophic rockfall of September 12, 1717 on the Italian flank of the Mont Blanc massif. Z. Geomorphol., 24, 200-218.

Post, A. (1968) Effects on glaciers. In: The Great Alaska Earthquake of 1964 - Hydrology, Pt. A, pp. 266-308. National Academy of Sciences, Washington, DC.

Rapp, A. (1959) Avalanche boulder tongues in Lappland. Geogr. Ann., 41, 34-48.

Scheidegger, A.E. (1973) On the prediction of the reach and velocity of catastrophic landslides. Rock Mechanics, 5, 231-236.

Schiefer, E. and Gilbert, R. (2007) Reconstructing morphometric change in a proglacial landscape using historical aerial photography and automated DEM generation.

Geomorphology, 88, 167-178.

Schulz, W.H., Harp, E.L. and Jibson, R.W. (2008) Characteristics of large rock avalanches triggered by the November 3, 2002 Denali Fault earthquake, Alaska, USA. In: 10th Intl.

Symposium on Landslides (Ed G. Deng), pp. 6, Xi'an, China.

Shreve, R.L. (1959) Geology and mechanics of the Blackhawk landslide, Lucerne Valley, California. Ph.D. thesis, California Institute of Technology, Pasadena, CA, 79 pp.

Shreve, R.L. (1966) Sherman landslide, Alaska. Science, 154, 1639-1643.

Shreve, R.L. (1968) Sherman landslide. In: The Great Alaska Earthquake of 1964 - Hydrology, Pt. A, pp. 395-401. National Academy of Sciences, Washington, DC.

Shulmeister, J., Davies, T.R., Evans, D.J.A., Hyatt, O.M. and Tovar, D.S. (2009)

Catastrophic landslides, glacier behaviour and moraine formation - A view from an active plate margin. Quat. Sci. Rev., 28, 1085-1096.

Stock, G.M. (2008) Cataclysmic rock avalanche from El Capitan, Yosemite Valley, circa 3.6 ka. In: American Geophysical Union, Fall Meeting 2008, H53G-07, San Francisco, CA.

Strom, A.L. (1996) Some morphological types of long-runout rockslides: Effect of the relief on their mechanism and on the rockslide deposits distribution. In: Proc. 7th Int.I Symposium on Landslides (Ed K. Senneset), pp. 1977-1982. Balkema, Rotterdam.

Strom, A.L. (2006) Morphology and internal structure of rockslides and rock avalanches; grounds and constraints for their modelling. In: Landslides from Massive Rock Slope Failure; NATO Science Series: IV, Earth and Environmental Sciences (Eds S.G. Evans, G. ScarasciaMugnozza, A.L. Strom and R.L. Hermanns), 49, pp. 305-326. Springer, Dordrecht.

Tovar, D.S., Shulmeister, J. and Davies, T.R. (2008) Evidence for a landslide origin of New Zealand's Waiho Loop moraine. Nature Geosci., 1, 524-526. 
Tuthill, S.J., Field, W.O. and Clayton, L. (1968) Postearthquake studies at Sherman and Sheridan Glaciers. In: The Great Alaska Earthquake of 1964 - Hydrology, Pt. A, pp. 318-328. National Academy of Sciences, Washington, DC.

Woodcock, N.H. (1977) Specification of fabric shapes using an eigenvalue method. Geol. Soc. Am. Bull., 88, 1231-1236. 


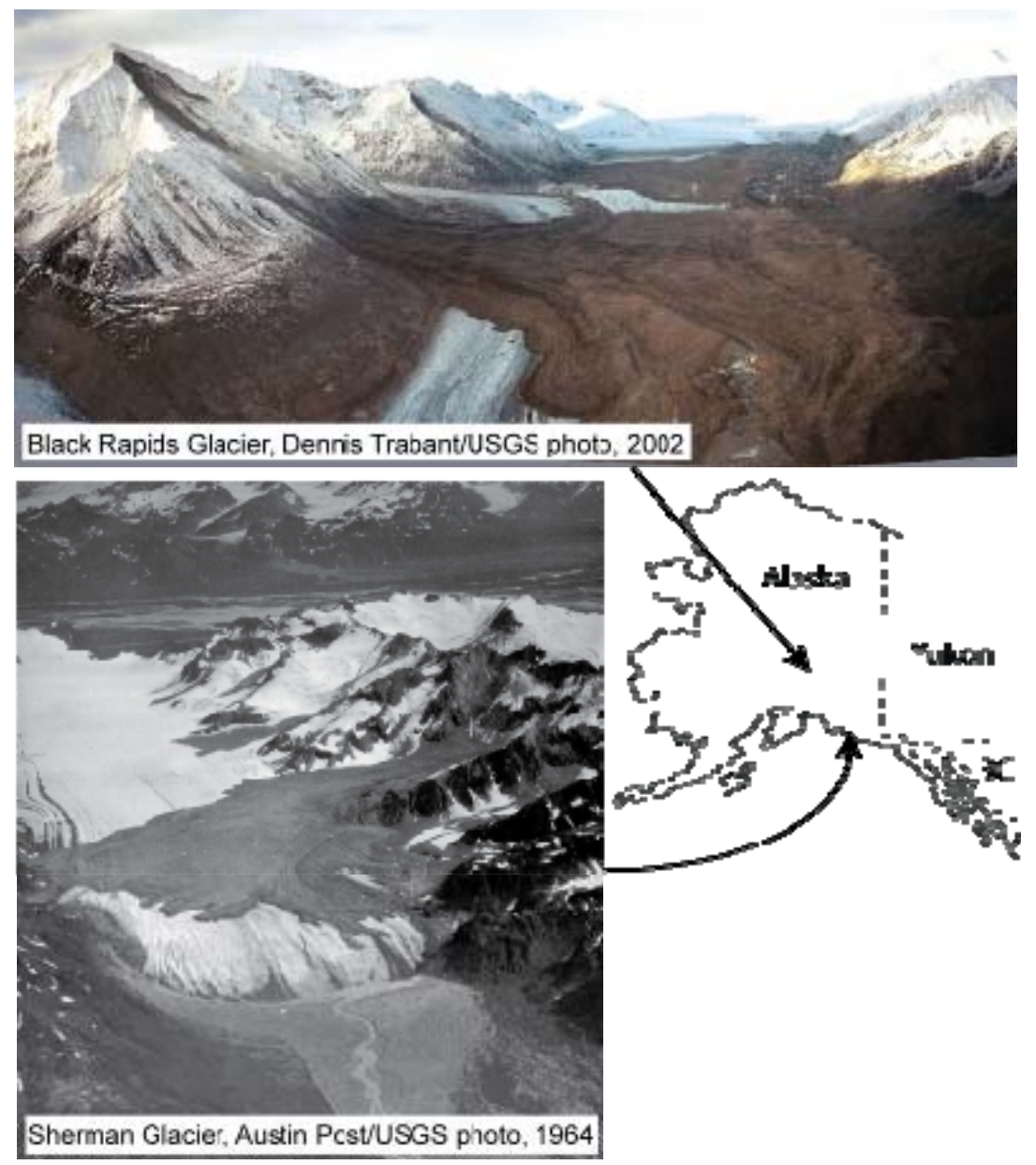

Figure 1 Locations of Black Rapids and Sherman glaciers and photographs of the landslide debris sheets. 

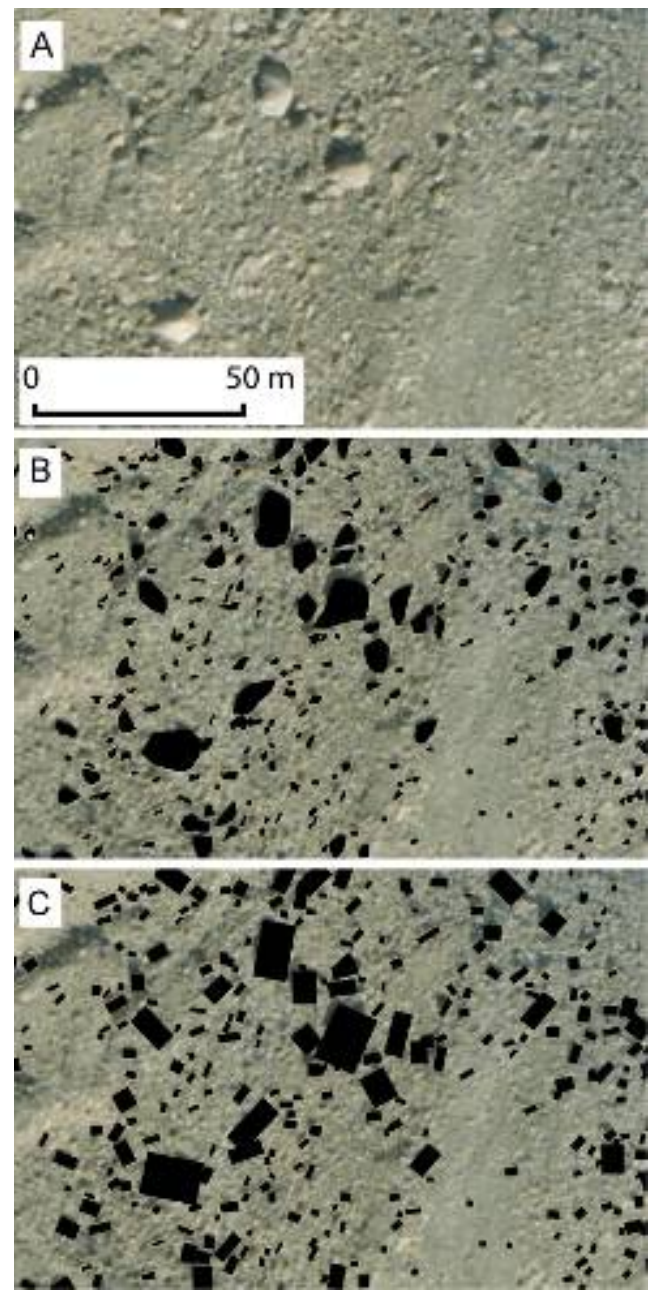

Figure 2 Example of digitized blocks on a landslide. A. The orthophoto used for digitizing. B. Manually digitized polygons. C. Minimum bounding rectangles around each block. 

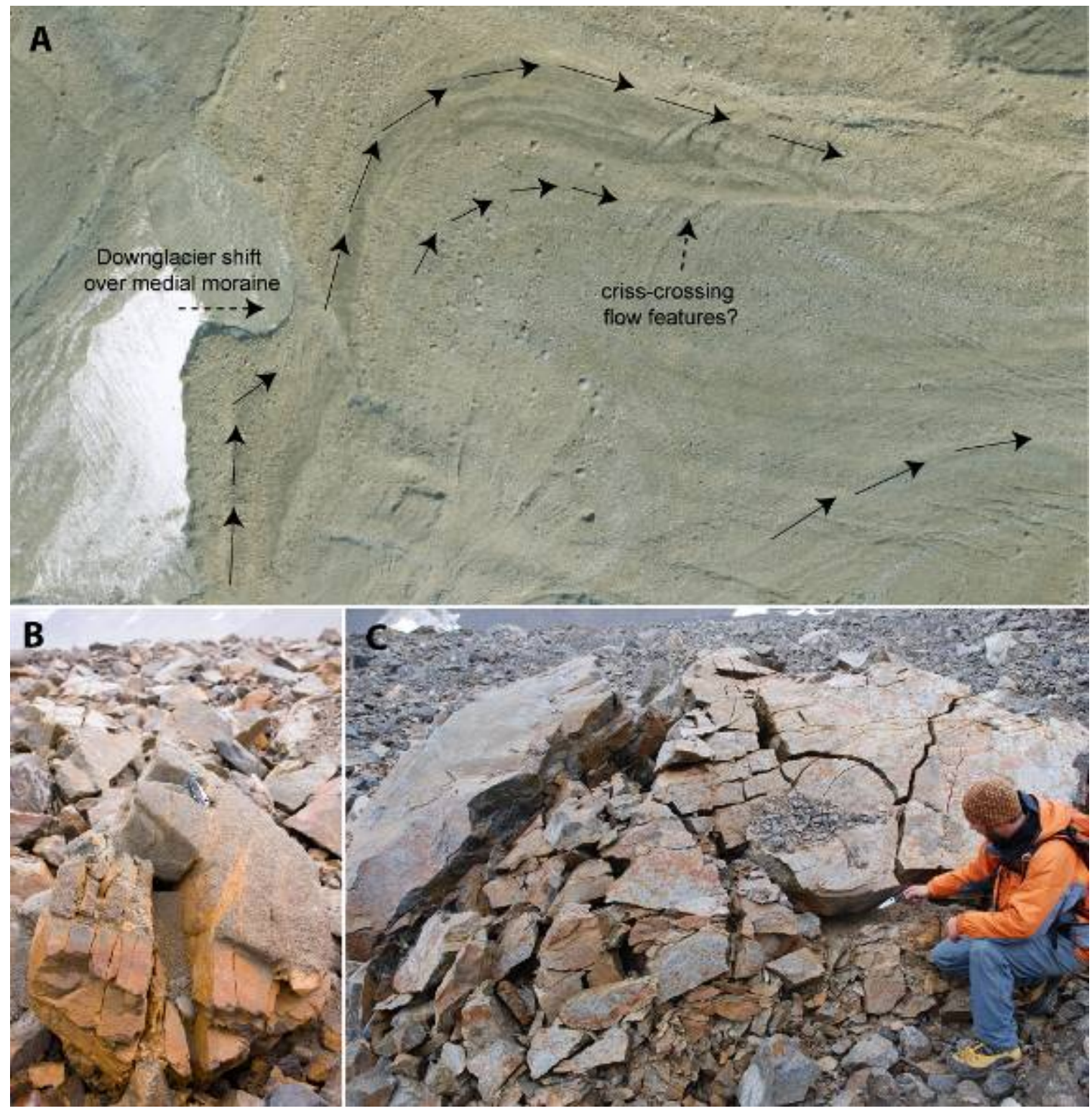

Figure 3 Photographs of rock avalanche debris on Black Rapids Glacier. A. Aerial photograph of northwest corner of 'BRG-middle', showing longitudinal flowbands (solid arrows) turning to the east near the lateral moraine on the north side of the glacier. The darker, finer stripe bounded by the middle and lower sets of arrows is discussed in section 4.4. Note apparent criss-crossing flow features and the downglacier deflection in flow where the debris surmounted the medial moraine (see text for discussion). B. Grusified block on BRG-west. The top half of the block is loose sand that retains the overall shape of the original block; the lower half is competent rock. Knife provides scale. C. Large jigsaw brecciated block on BRG-west. 

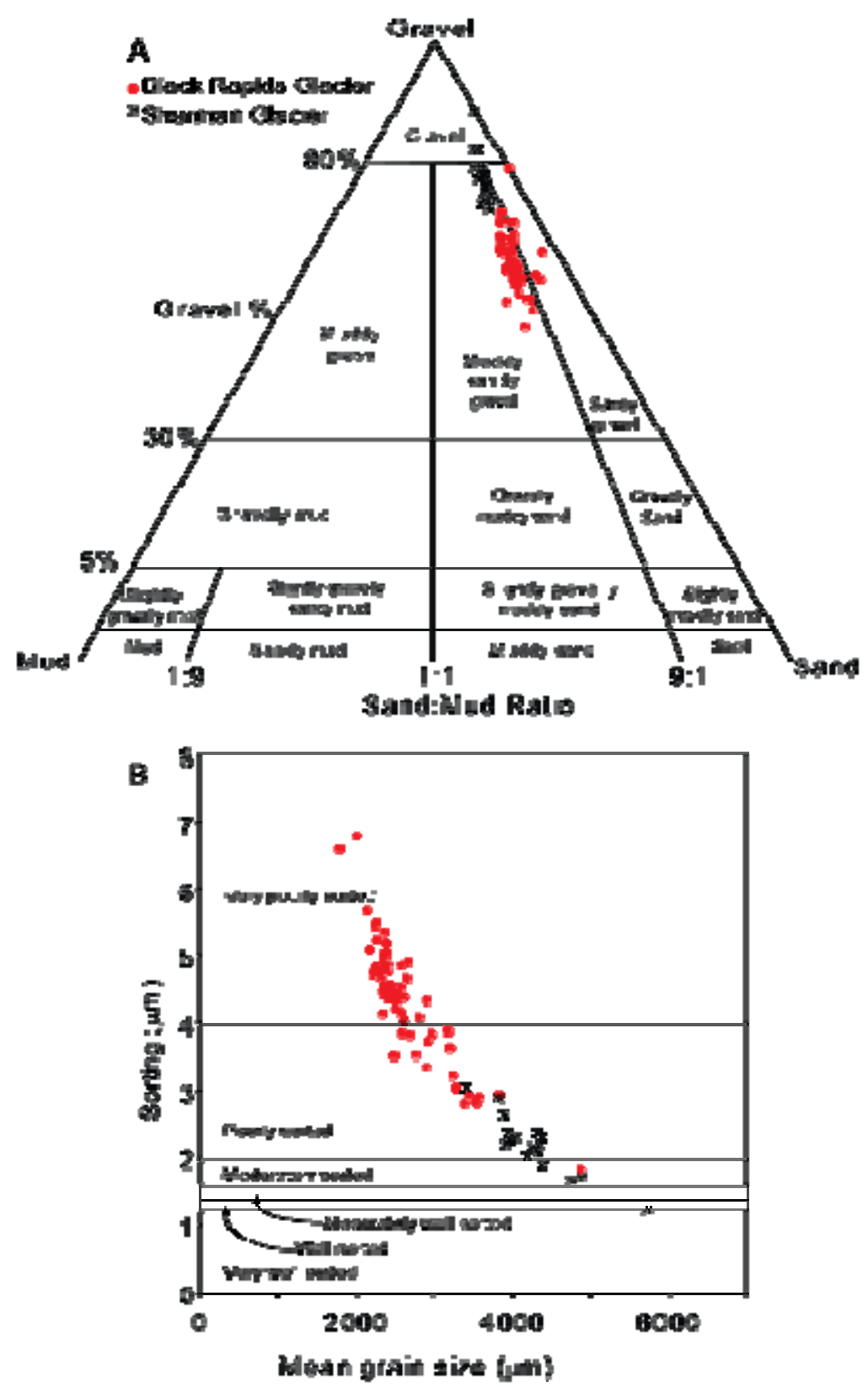

Figure 4 A. Particle size of landslide debris on Black Rapids and Sherman glaciers. B. Sorting as a function of mean particle size of landslide debris matrix on Black Rapids and Sherman glaciers. Data are analyzed using the geometric method of Folk and Ward (1957) and are from 2007 (BRG-west) and 2008 (Sherman Glacier). 


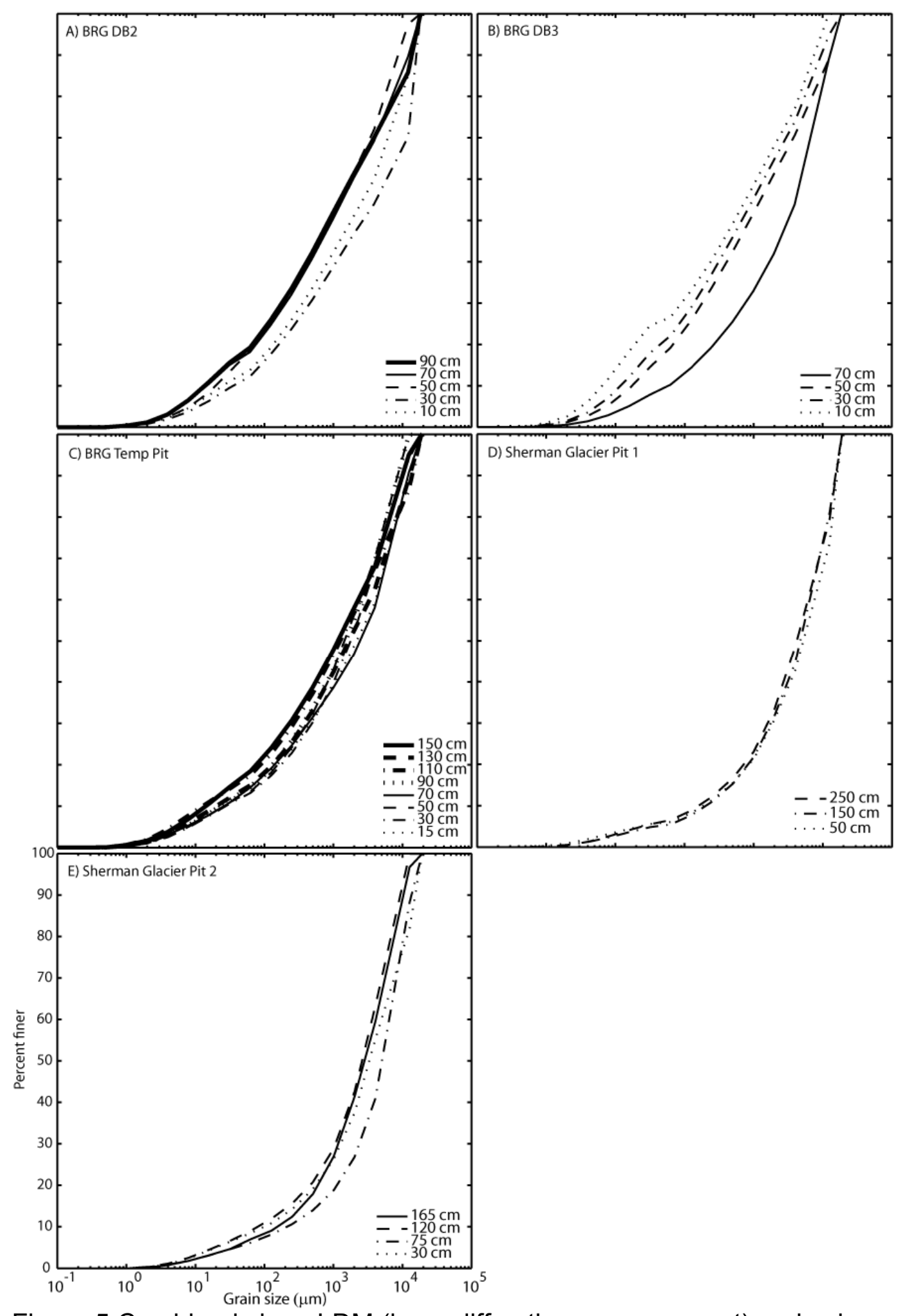

Figure 5 Combined sieve-LDM (laser diffraction measurement) grain size curves for fine material collected from three vertical profiles within the BRG-west debris sheet $(A, B, C)$, and from two profiles within the Sherman Glacier debris sheet (D, E). Distances are centimeters above the ice-rock interface. 


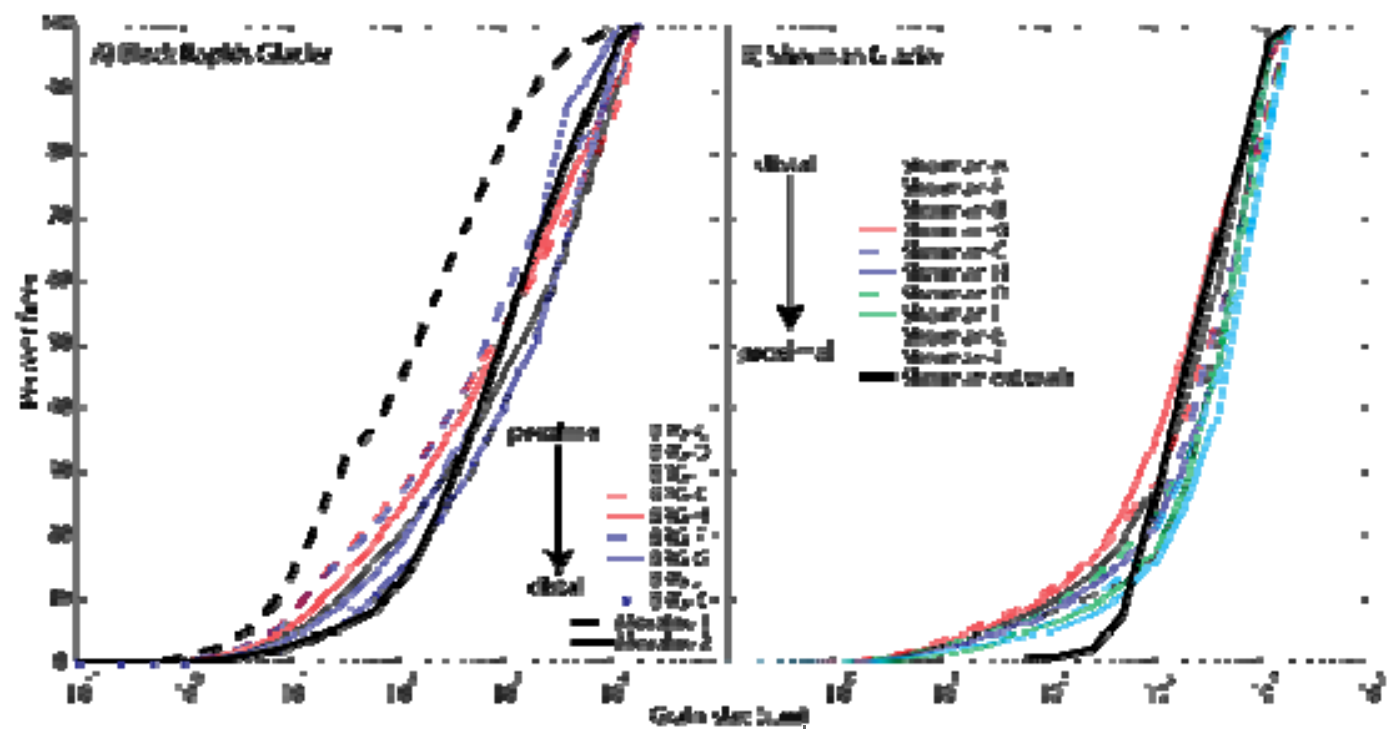

Figure 6 Combined sieve-LDM grain size curves for fine material on $(A)$ the surface of the BRG-west landslide and (B) the surface of the Sherman Glacier landslide. Sampling locations are shown in Figure 7. 
A
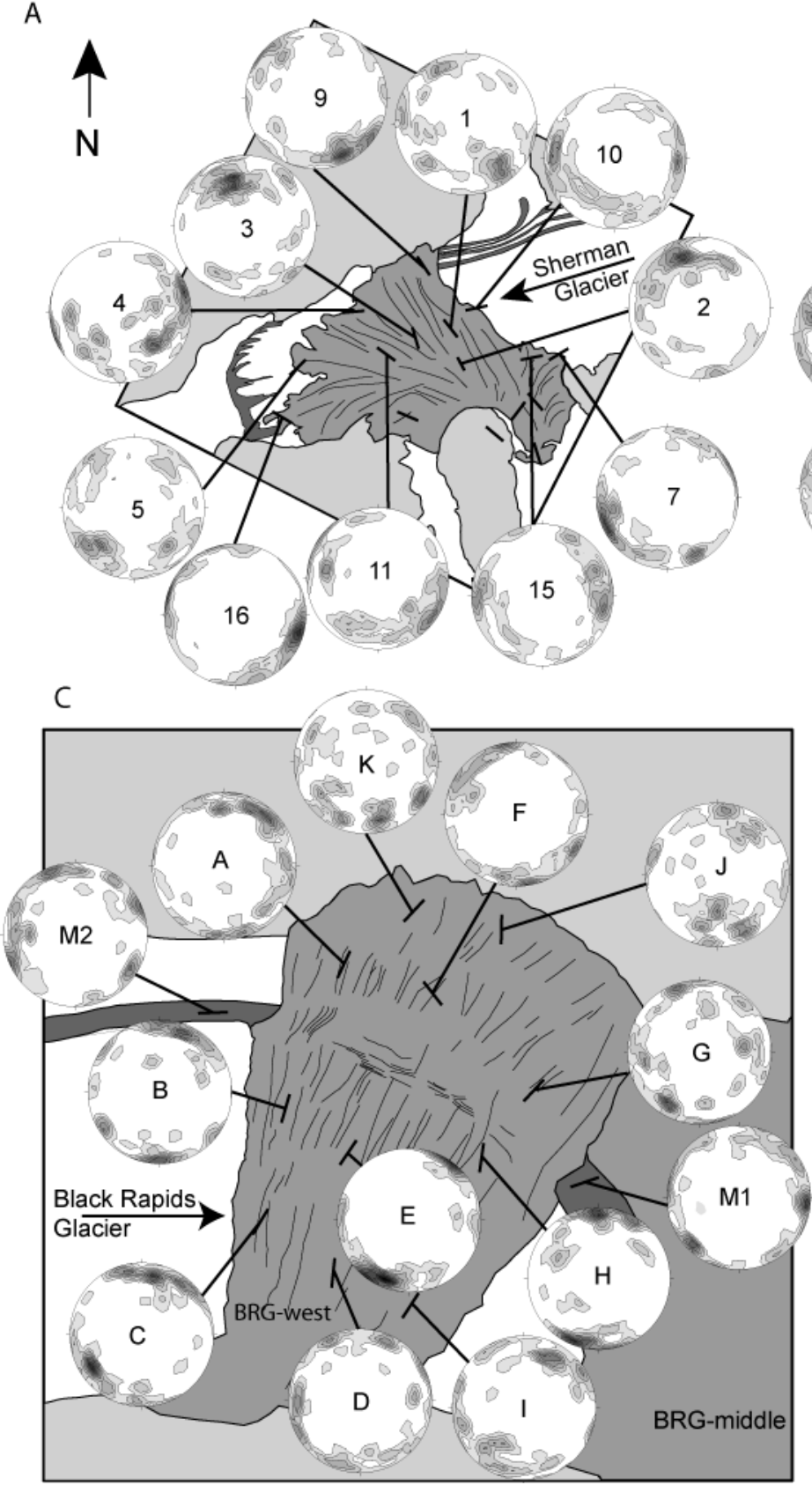

B

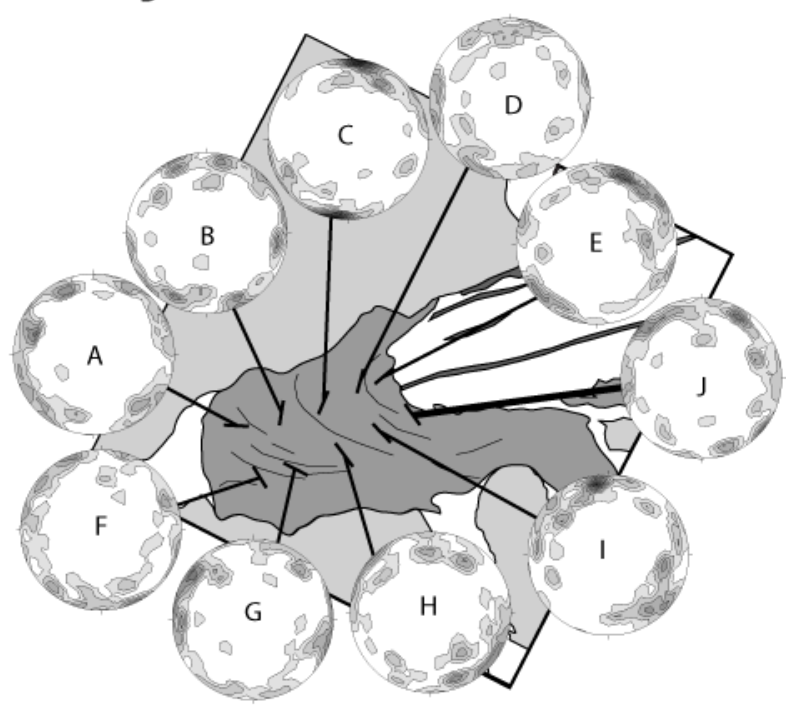

D

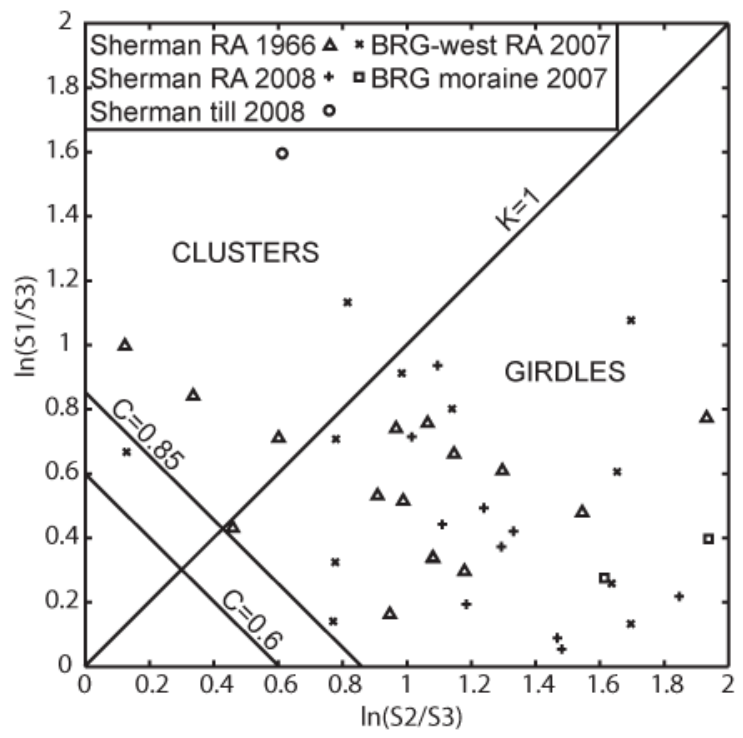

Figure 7 Maps of fabric measurements and eigenvectors for landslides on (A) Sherman Glacier in 1966 and (B) 2008, and (C) BRG-west in 2007 (C). Eigenvectors in A, B and C are represented by short lines at the end of the leaders that show the stereonet locations. $D$. Eigenvalue ratio graph for Sherman Glacier landslide and BRG-west. The solid line extending from the origin $(\mathrm{K}=1)$ separates fabric clusters and girdles. The two lines perpendicular to the cluster-girdle transition line represent $C=0.85(N=50)$ and $C=0.6(N=100)$, where $C=\ln \left(S_{1} / S_{3}\right)$. Fabrics that plot above $\mathrm{C}=0.85$ are significant at the $99 \%$ level, whereas those that plot between the lines are significant at the $97.5 \%$ level. 

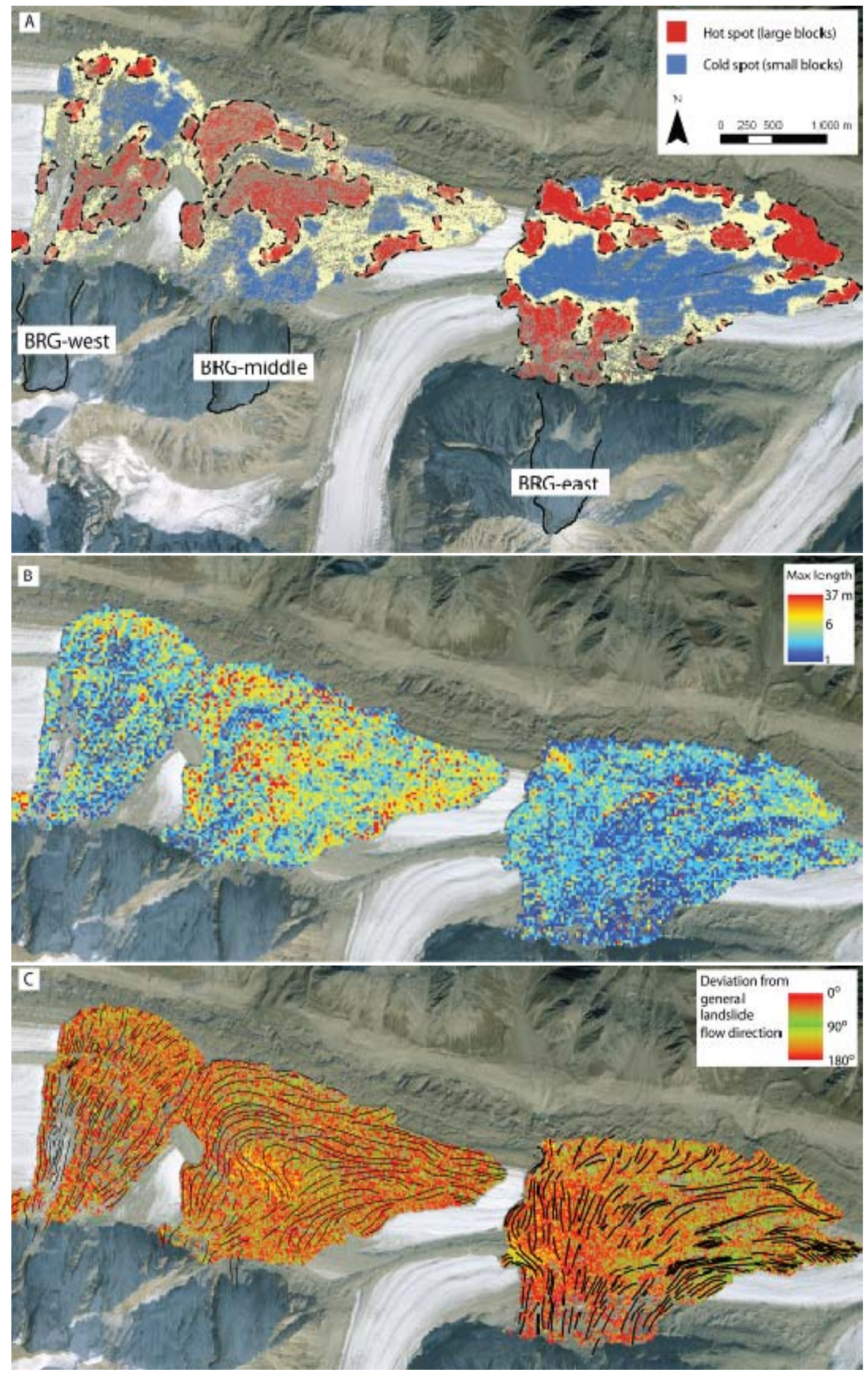

Figure 8 Maps of $(A)$ block size (Hot Spot) clusters, (B) maximum block length, and (C) deviation from the general flow direction for the Black Rapids Glacier landslides; the maps overlie an orthophoto mosaic. The source scars are delineated in A. Interpreted flowbands are shown in $\mathrm{C}$. 

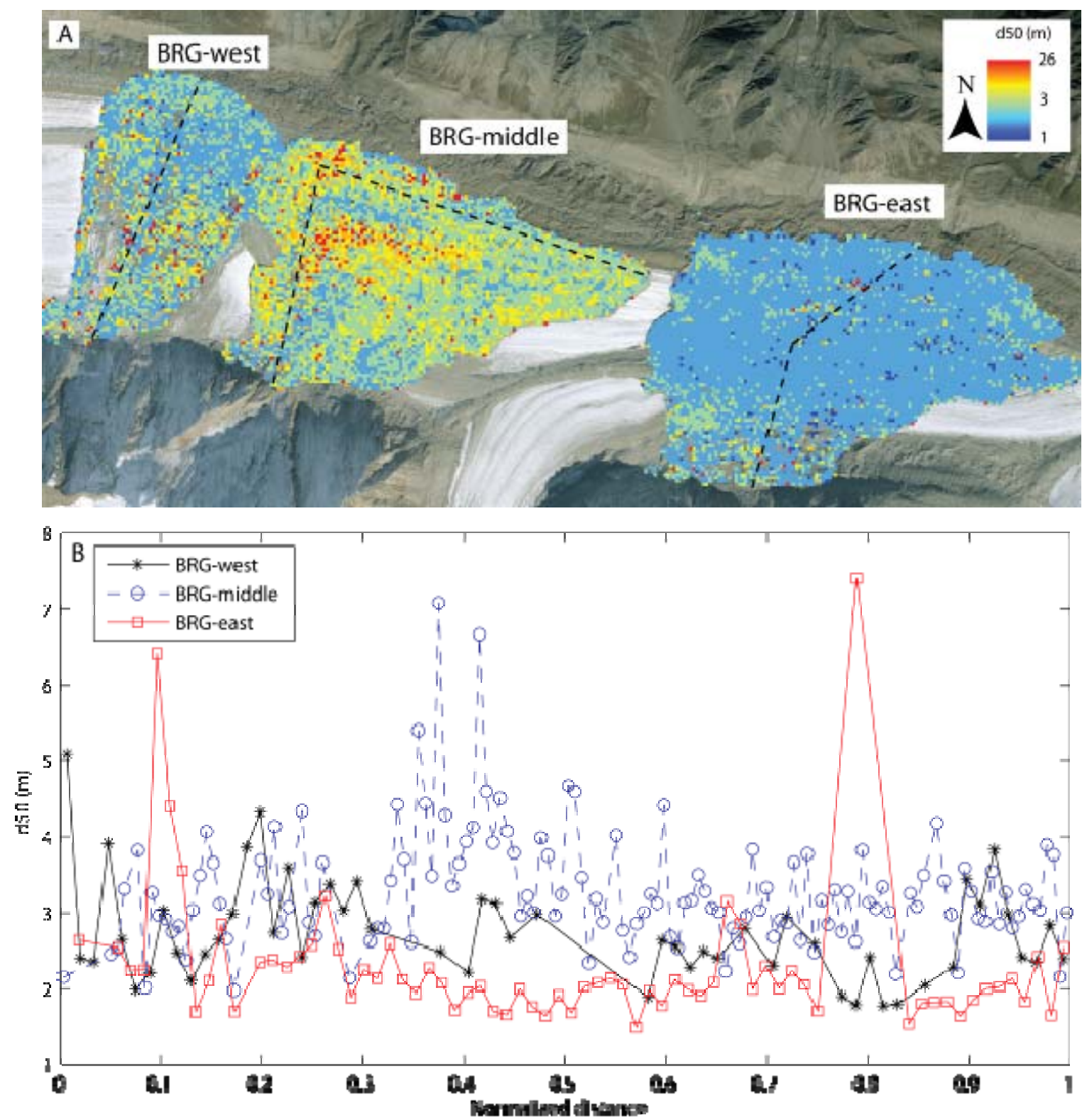

Figure 9 Relation between median block length and transport distance. A. Neighborhood d50 of blocks >1 m2; dashed lines show locations of transects shown in B. Each data point in $B$ is the median block size within a $30 \mathrm{~m}$-diameter circle. Median block size was calculated only for circles containing at least three blocks. 


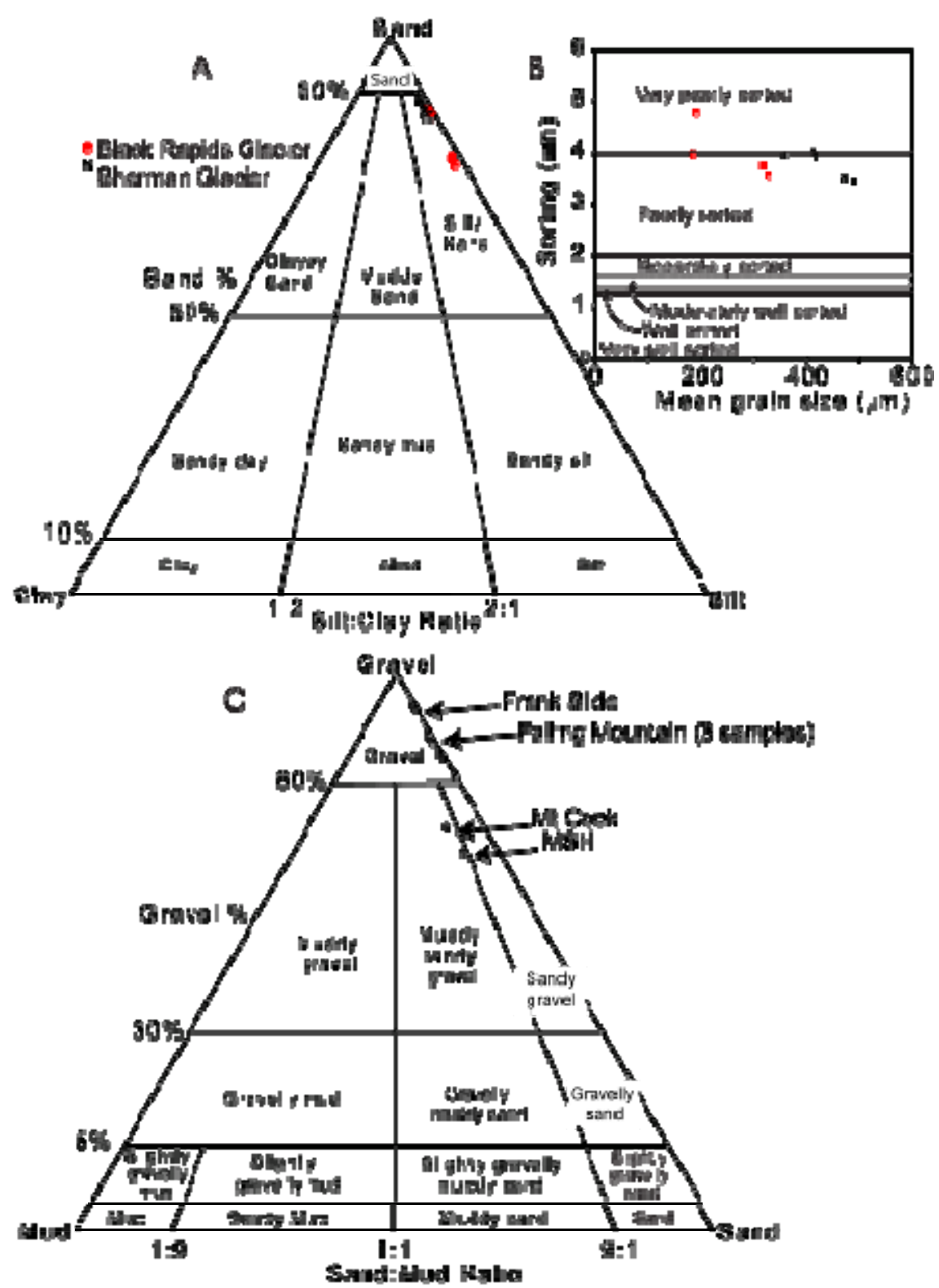

Figure 10 A. Particle size of crushed debris from Black Rapids and Sherman glaciers. B. Sorting as a function of mean grain size for crushed material from Black Rapids and Sherman glacier debris; sorting calculated using the geometric Folk and Ward (1957) method. C.Particle size of matrix of other large rock avalanches, including Falling Mountain (1929), Acheron ( 1100 yr BP), Coleridge ( 700 yr BP), Round Top ( 1070 yr BP), Frank Slide (1903), Mt. Cook (1991), and Mount St. Helens (1980). Data for C provided by M. McSaveney, GNS Science, New Zealand. Some sites have more than one data point. 